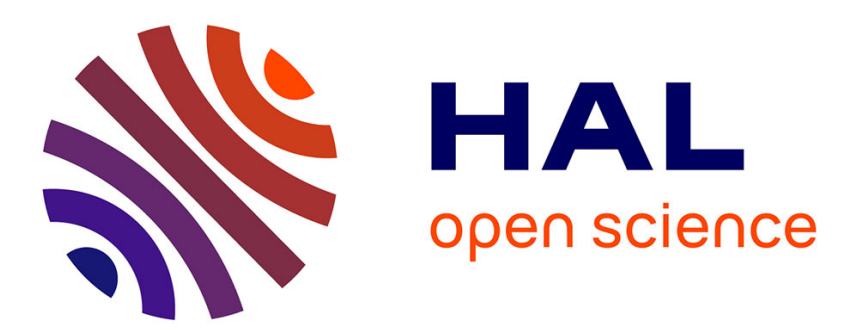

\title{
Bank Office Outreach, Structure and Performance in Regional Banking Markets
}

\author{
Johann Burgstaller
}

\section{To cite this version:}

Johann Burgstaller. Bank Office Outreach, Structure and Performance in Regional Banking Markets. Regional Studies, 2011, pp.1. 10.1080/00343404.2011.607809 . hal-00758599

\section{HAL Id: hal-00758599 \\ https://hal.science/hal-00758599}

Submitted on 29 Nov 2012

HAL is a multi-disciplinary open access archive for the deposit and dissemination of scientific research documents, whether they are published or not. The documents may come from teaching and research institutions in France or abroad, or from public or private research centers.
L'archive ouverte pluridisciplinaire HAL, est destinée au dépôt et à la diffusion de documents scientifiques de niveau recherche, publiés ou non, émanant des établissements d'enseignement et de recherche français ou étrangers, des laboratoires publics ou privés. 


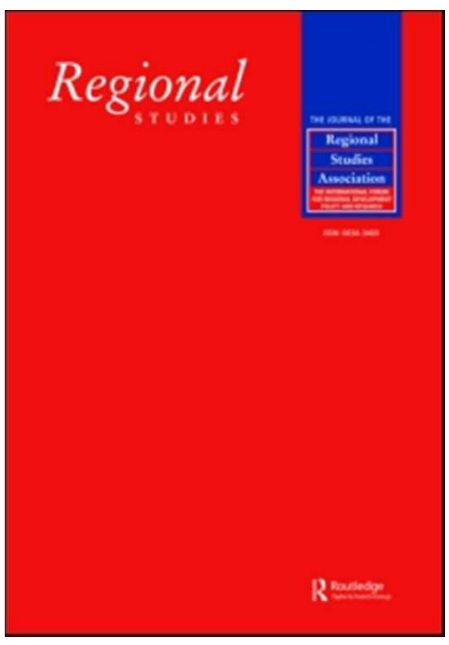

\section{Bank Office Outreach, Structure and Performance in Regional Banking Markets}

\begin{tabular}{|r|l|}
\hline Journal: & Regional Studies \\
\hline Manuscript ID: & CRES-2010-0254.R1 \\
\hline Manuscript Type: & Main Section \\
\hline JEL codes: & $\begin{array}{l}\text { G21 - Banks|Other Depository Institutions|Mortgages < G2 - Financial } \\
\text { Institutions and Services }<\text { G - Financial Economics, L11 - Production, } \\
\text { Pricing, and Market Structure|Size Distribution of Firms }<\text { L1 - Market } \\
\text { Structure, Firm Strategy, and Market Performance < L - Industrial } \\
\text { Organization, R32 - Other Production and Pricing Analysis < R3 - } \\
\text { Production Analysis and Firm Location < R - Urban, Rural, and Regional } \\
\text { Economics }\end{array}$ \\
\hline Keywords: & $\begin{array}{l}\text { bank outreach, local markets, market structure, competition, bank } \\
\text { performance, regional development }\end{array}$ \\
\hline \multicolumn{2}{|l}{} \\
\hline
\end{tabular}

\section{SCHOLARONE}

Manuscripts 


\title{
Cris: please not that the author provided the German abstract
}

\section{Bank Office Outreach, Structure and Performance in Regional Banking Markets}

\author{
JOHANN BURGSTALLER \\ Finance Department, University of Linz, Freistädterstr. 315, A-4040 Linz, Austria. \\ Email: Johann.Burgstaller@jku.at
}

(Received July 2010: in revised form July 2011) 
BURGSTALLER J. Bank office outreach, structure and performance in regional banking markets, Regional Studies. This paper studies bank penetration, market structure and banking conduct across Austrian districts. Neither differences in market concentration nor in the activity of out-of-market banks can explain the regional dispersion of interest rates, bank profitability and efficiency. A higher bank density is connected to more competition and lower markups, and indicates more efficient banking markets as well. As efficiency is the main determinant of bank profits and competition seems to be (mildly) indicative of stronger regional growth, the preservation of a fair regional bank outreach appears to be an important policy target.

Bank outreach Local markets Market structure Competition Bank performance Regional development

BuRgstalleR J. Bankstellendichte, Marktstruktur und Performance in regionalen Bankenmärkten, Regional Studies. Die vorliegende Arbeit untersucht Bankendispersion, Marktstrukturen und Bankverhalten auf der Ebene von Bezirken in Österreich. Weder Unterschiede in der Marktkonzentration noch in der Dichte nicht bezirksansässiger Banken tragen zur Erklärung der Variation in Bankzinsen, Profitabilität und Effizienz bei. Eine höhere Bankendichte steht in Verbindung mit verstärkter Konkurrenz und niedrigeren Aufschlägen und ist auch ein Indiz für höhere Bankeneffizienz. Da Effizienz die Hauptdeterminante für die Gewinne der Banken darstellt und stärkerer Wettbewerb zwischen Banken positiv mit regionaler Entwicklung verbunden scheint, ist die Erhaltung einer gewissen Bankendichte durchaus ein erstrebenswertes wirtschaftspolitisches Ziel. 
Bankstellendichte Lokale Märkte Marktstruktur Wettbewerb Bankenperformance Regionalentwicklung

JEL classifications: G21, L11, R32

\section{INTRODUCTION}

The influence of the financial system on regional structures and disparities has long been neglected due to the predominance of the neoclassical view of space-neutral money (KLAGGE, 1995; MARTIN, 1999). In recent times, however, both economists and policymakers have recognized and highlighted capital market imperfections that may lead to diverging access to finance and economic development across regions. The role of information in assessing borrower quality and related technological advances is one main topic in this respect, a second deals with competition in banking markets and the effects of consolidation tendencies on bank efficiency, customer welfare and economic growth. Opinions of bankers, politicians as well as researchers seem divided related to the probability and necessity of further concentration, the need of a breakup of local banking structures, and the potential consequences. CHAKRAVARTY (2006) and REHM (2008), for example, describe the growing political pressures due to competition concerns, overbanking and low profitability with respect to the German case. The European Commission recently has conducted an inquiry into factors that hamper competition in European banking markets such as cooperation practices and market segmentation (EUROPEAN COMMISSION, 2007), which are prevalent especially for locally oriented nonprofit banks. A widespread view is that the abolishment of anticompetitive structures, as well as the ongoing technological progress and consolidation will lead to a more efficient banking system and potential benefits for all involved parties. However, there also is the concern about adverse effects from these developments on bank-customer relationships 
with spatially varying consequences for the access to finance and economic development. If this view is correct, there is a case for local banking and capital markets (KLAGGE and MARTIN, 2005).

This study focuses on regional banking markets within the country of Austria. Against the background of the developments described above, it examines the local branch outreach of banks (also by bank type) and its connections to interest rate levels, bank profits and efficiency, competition intensity and economic development. Furthermore, empirical evidence is provided on the determinants of all these variables at the regional level. The Austrian case can be filed as follows. On the one hand, market coverage by savings banks and credit cooperatives is considerable, as is the prevalence of issues and practices that are presumed to hinder competition (specific ownership structures and regulatory rules, cooperation between banks and territorial principles). In this respect, Austria is not uncommon, as both attributes also apply to many other European countries, although to a varying degree (EUROPEAN COMMISSION, 2007). But then, fewer similarities may be present with respect to other features, which limits the possibility to generalize the presented results. Such characteristics contain the economic importance of small and medium-sized enterprises (SME) and their dependence on bank finance (which both are high for Austria), the development of equity capital markets (which is low), and the strength of different government levels and interest groups in political decisions related to banking and financial matters.

Besides the novelty of considering the Austrian case, the contributions to the literature on regional banking are as follows. First, this paper applies regions as observational units, which is rarely done in banking studies. While regional influences on bank conduct and behavior can be studied at the bank level, other aspects can be addressed more sensibly or more directly at the regional level, such as financial development, economic growth and market integration. The applied geographical focus also allows a comprehensive assessment of banking markets. Previous empirical evidence 
at the regional level appears rather fragmented as, in many cases, it is restricted to one measure to be explained or sometimes even to a bivariate relation only (for example, distance and credit availability, competition and interest rate levels, and so on). Second, the analysis is not restricted to certain types of institutions as it is frequently done with respect to savings banks. Third, the size of the examined markets is presumed to, more or less, represent the effective action scope of both banks and customers. Partly comparable studies are often conducted for much larger territorial units (e.g. USAI and VANNINI, 2005; Carbó-Valverde, lópez del Paso and Rodríguez-Fernández, 2007; Coccorese, 2008), though survey evidence suggests that geographical banking markets may actually be smaller than districts (AMEL and BREVOORT, 2005). Finally, the applied methods account for possible spatial dependencies between regions which are typically ignored in similar studies. It is thus possible to test whether districts are spatially unrelated with respect to certain attributes, with the test outcomes also providing hints on the actual extent of banking market segregation.

The remainder of the paper is organized as follows. Section 2 provides the theoretical and conceptual framework for studying regional banking markets. Additional to introducing the fields to be studied, it elaborates on research related to regional economic growth, financial exclusion, market delineation, financial politics, as well as on some ongoing trends in banking. Section 3 describes the Austrian banking landscape and the applied data. The variables considered include regional bank outreach, population and economic structure, gross regional product and income growth, several market structure indicators, regional banking sector development and interest rate levels, banking profitability, efficiency and competitive behavior. A descriptive investigation of bank office outreach in Austria (also by bank types) in light of market structures is to be found in Section 4, and in Section 5, measures of conduct generated from bank-level financial data are added to the discussion. This part also analyzes several relationships that frequently appear in the empirical literature, though not necessarily related to regional data. The analysis, however, 
is static as mainly data from one year (2006) are evaluated. As a first consequence, the results are only indirectly related to the dynamic process of bank consolidation and the growing competitive pressures due to globalization and technological changes (described, for example, by ConRAd, Neuberger and SchneIDER-ReißIG, 2009). This does not seem overly problematic as consolidation has not tremendously affected the Austrian banking landscape up to now. Acquisitions are rare and mergers mainly occur within a particular sector, and mostly between small, locally oriented banks (HAHN, 2007a). Secondly, bank office location has to be assumed exogenous in the interpretation of the results. Therefore, the emphasis is put upon the revelation of associated variables, not on strict inference about causal effects. The final section summarizes the results and discusses their implications.

\section{REGIONAL BANKING MARKETS}

Spatial development policies are rationalized by the fact that interregional disparities proved to be long-term persistent (CAMAGNI and CAPELLO, 2010), suggesting that neoclassical convergence through spillovers and diffusion processes is impeded. Location factors thus are important, motivating the role of economic geography for spatial planning and regional policy evaluation (CLINCH and O'NeILL, 2009; POTTER, 2009; MARTIN and SUNLEY, 2011). ${ }^{1}$ The crucial component of regional development (besides national factors) is the internal development capability, the so-called "territorial capital" (CAMAGNI and CAPELLO, 2010). While many different aspects are subsumed by this term (infrastructure, human capital, innovation, and many more), the development and quality of the financial system is not considered to be equally important.

This neglect is consistent with the view that financial markets and institutions are passive intermediaries which channel capital toward its most productive usage (KLAGGE, 1995; MARTIN, 1999). A "more realistic" view, however, asserts that the financial system has a key role for regional economic development, especially through the financing of new 
and small firms (KLAGGE and MARTIN, 2005). ${ }^{2}$ Due to imperfections in capital and banking markets, the spatial organization of (local) financial systems is important for regional growth, as well as the environmental factors that are shaping these systems (KLAGGE, 1995; ChAKRAVARTY, 2006). Constraints to capital mobility, for example, form the basis of the so-called finance-growth nexus (the respective literature is surveyed by LEVINE, 2005), which implies that the quantity of credit available is a determinant of economic activity. A relation of bank financial deepening (measured by bank credit relative to GDP) and income growth seems to be present at the regional level as well (GUISO, SAPIENZA and ZINGALES, 2004; CARBÓ-VALVERDE et al., 2007; VAONA, 2008).

A more extensive strand of the literature emphasizes the role and the consequences of informational frictions in credit markets. In this line of argument, especially small business financing depends on the use of soft information on borrower quality, which requires proximity and close bank-customer relationships. ${ }^{3}$ The common opinion has been that small banks with regional roots and a strong commitment to local affairs have a comparative advantage in the gathering and processing of soft information and therefore provide more (stable) credit to informationally opaque borrowers. ${ }^{4}$ The importance of lender-borrower proximity implies that retail banking markets are local by nature. ${ }^{5}$ The majority of retail banks has a regionally limited focus, while "loan and deposit customers shop for banking services in rather narrowly defined markets" (FISCHER and PFEIL, 2004). Furthermore, empirical evidence suggests that bank-customer proximity does not seem to lose (much) importance because of deregulation and technological changes (BREVOORT and Hannan, 2006; Brevoort and Wolken, 2009; Alessandrini, Presbitero and ZAZZARO, 2009c).

The above assertions also imply that bank outreach is vital, especially for lagging and peripheral - and thus rather unprofitable - regions (KLAGGE, 1995; CHAKRAVARTY, 2006). A withdrawal of financial institutions from such areas due to, for example, competitive pressures may threaten the access to finance and thus lead to so-called "finance gaps" 
(KLAGGE and MARTIN, 2005). Consequently, regional disparities are amplified and the concerned regions may become financially "deserted" (CHICK and DOW, 1988; LEYSHON and THRIFT, 1995; MARTIN, 1999; Dow, 1999; GÄRTNER, 2009a). Associated concerns have turned financial exclusion into a prominent academic and policy issue. BECK and DEMIRGüç-KunT (2008), for example, provide a review in this respect. From a crosscountry perspective, bank outreach is found important for economic growth through improved access to finance and the promotion of firm entry (BECK, DEMIRGÜÇ-KUNT and MARTINeZ PERIA, 2007). Recently, financial exclusion has been assessed at the European level (EUROPEAN COMmission, 2008), and the European Commission launched a program that is designed to address regional disparities in the financing possibilities of small businesses.

The effective threat of an underprovision with financial services, however, depends on which types of banks serve, enter and exit the regional markets and how these institutions deal with various developments that may affect their (lending) behavior. ${ }^{6}$ Local banks are considered being of utmost importance in this respect due to their special characteristics. Collender and ShAFFER (2003) list these attributes, which consist of a superior access to local information, a focus on relationship lending, a greater commitment to regional prosperity, and some protection from competition (due to legal restrictions or a voluntary market demarcation). These features are characteristic for local (non-profit) banks such as savings banks and credit cooperatives, which explains that these institutions are at the center of attention where they are prominent. In Germany, for instance, savings banks are legally obliged to serve local interests and regional development, which prevents a drain of capital from poorer regions and hence facilitates local economic growth (GÄRTNER, 2009a; HAKENES, SCHMIDT and XIE, 2009; SCHMIDT, 2009). As cooperative banks pursue a comparable regional market delineation (the socalled "regional principle"), they should play a role similar to that of savings banks (SCHMIDT, 2009). Similar structures are prevalent in Austria and other European countries, 
and the relative outreach of such local banks should be helpful to explain regional differences in bank conduct and performance, as well as in local development, both across regions and time.

Different aspects related to deregulation and consolidation in banking markets have been studied with respect to their effects on small business lending and economic growth. For example, credit availibility is often found to deteriorate due to bank M\&A activities, but these effects are mostly temporary because of subseqent market entry and credit extension by other (local) banks (BERGER, SAUNDERS, SCALISE and UdELL, 1998; BeRGER, Bonime and Goldberg, 2004a; Bonaccorsi DI PATTI and GobBI, 2001, 2007; Ely and ROBINSON, 2009). These results are consistent with positive growth effects reported in the wake of bank branch deregulation in the USA (JAYARATNE and STRAHAN, 1996; COLLENDER and SHAFFER, 2003), but FREEMAN (2007) argues that these are (at best) temporary as well. BONACCORSI DI PATTI and GOBBI (2001), for example, find a positive relation between bank branch density and growth in the regional context (for Italy). The most severe threat on credit provision, however, does not seem to stem from consolidation per se, but from the centralization of decision-making (AlessandrinI, PREsBitero and ZAZZARO, 2009a,b, 2010). An associated loss of local knowledge and its reliability (KLAGGE and MARTIN, 2005), as well as of social interactions and contact (MARTIN, 1999; CHAKRAVARTY, 2006), will increase difficulties for small firms in peripheral regions to access funds. In particular, it becomes harder to obtain specialized and personalized products (KLAGGE, 1995; CHAKRAVARTY, 2006). A connected issue is the intensified usage of automated information gathering through, for example, credit scoring methods. If soft information on borrower quality proves inadequate to be processed within such systems, further financial provision troubles can be expected (BREVOORT and WOLKEN, 2009; GÄRTNER, 2009a; UDELL, 2009).

Besides bank outreach, consolidation also affects competition and concentration in local banking markets. The traditional "market power view" (CARBÓ-VALVERDE, RodRíGUEZFERNÁNDEZ and UDELL, 2009) asserts that reduced competition and more concentration 
lead to a subsequent rise in lending rates, with detrimental effects on credit and growth. On the other hand, it is frequently argued that a more competitive environment reduces the incentives to engage in relationship lending with subsequent reductions in small business lending (PETERSEn and RAJAN, 1995; VerdieR, 2000). Empirical evidence in favor of the latter view is provided, for example, by FERNÁNDEZ DE GUEVARA and MAUDOS (2009), who find that a certain level of local market power promotes the use of soft information and thus facilitates regional growth. A positive relation between market concentration and local economic growth is reported by HASAN, KoETTER and WedOW (2009) and CARBÓ-VALVERDE et al. (2009). However, it has become increasingly evident that competitive behavior is hardly deducible from measures of market structure such as concentration (SHAFFER, 2004; Fernández de Guevara, Maudos and Pérez, 2005; MerciecA, Schaeck and Wolfe, 2009). Furthermore, evidence is emerging that finds increasing competition not being as detrimental to bank-customer relationships as possibly presumed (ELSAS, 2005; DEGRYSE and ONGENA, 2007; MERCIECA et al., 2009). Additional, outright positive consequences of deregulation are increases in welfare not only through lower lending rates, but through competition forcing banks to become more efficient (WILLIAMS and GARDENER, 2003; CHAKRAVARTY, 2006). Interpreting efficiency as a quality measure of financial development, HASAN et al. (2009) find that a more efficient financial intermediation is a predictor of regional growth.

Against the background described above, regional studies seem expedient to explore the differences in local bank penetration, market structures, bank performance and economic development, as well as the associated interrelations. The paper at hand fathoms the Austrian example based on a cross-section of regional units delineated by district borders. Further, more specific literature on regional banking markets is discussed with the respectice empirical results in Section 5. At this point, two more general issues shall yet be addressed. First, applying regional demarcations presumes that local markets are not (fully) integrated (USAI and VANNINI, 2005). Regional principles, as pursued by 
prominent bank groups, determine the markets' local nature from the banks' view, but also limit capital mobility and prevent the regional alignment of interest rates (USAI and VANNINI, 2005). Additionally, the fragmentation of markets, assisted by features of the network systems of savings banks and credit cooperatives, reduces competition between banks (SCHNABEL and HAKENES, 2007; SCHMIDT, 2009). Another disadvantage of the local orientation stems from reduced risk diversification. Regional banks are more prone to economic shocks as their attention is focused on distinct, locally present industries (SCHNABEL and HAKENES, 2007). Consequently, a trade-off appears to be present between the role of such banks for a sustained access to financial services and the welfare losses from the described practices.

Furthermore, a regional approach demands a definition of relevant markets which considers customer behavior alongside the observed scope of bank branching networks. Evidence on the extent of the area in which customers seek to obtain banking services predominantly comes from the USA where regular surveys are conducted among small businesses and households. ${ }^{7}$ In default thereof in European countries, only anecdotal reports such as DEGRYSE and ONGENA (2005) and NEUBERGER and RÄTHKE (2009) provide some related figures (i.c. for Belgium and Germany). As for the USA (PETERSEN and RAJAN, 2002; Amel and BreVoort, 2005; BREVOort and WolKEN, 2009), median distances reported by small business customers are rather low. In this respect, the (by far) largest figure emerges in BREVOORT and WOLKEN (2009) with about 11 miles for loans to small US firms. Median distances also did not exhibit strong increases over time, which is, however, the case for averages, suggesting more intense movements in the tail of the distance distribution (BREVOORT and WOLKEN, 2009). Two general results seem to emerge from this type of literature. First, markets as perceived by small businesses are considerably smaller than those employed by antitrust authorities and those typically applied in banking research (AMEL and BREVOORT, 2005). Second, these markets are smaller for checking and savings accounts than for loans (BREVOORT and WOLKEN, 2009). 
There are, however, some caveats to be issued (AMEL and BREVOORT, 2005). On the one hand, the described surveys do not explicitly sample the customers' online banking behavior. Additionally, customer-level markets overlap and a potential transmittal of competitive forces across their borders may yet bring about that the larger market definitions applied are not necessarily inappropriate.

Market definition is fundamental to, for example, competition analysis in banking (AMEL and BREVOORT, 2005). Thus, studies of bank conduct and behavior at the regional level should as well orientate the observational unit on effective delineations of geographical markets. In reality, however, the scope of the geographical units to be examined is typically based on either data availability (administrative units or other areas for which data are collected) or on a presumed size of local banking markets. ${ }^{8}$ These presumptions may be derived from the sellers' perspective (e.g. by looking at the sprawl of branch networks) or from customer surveys (as discussed above). It is rarely attempted to provide information on whether these conveniently delineated markets actually represent independent observational units. One of the few exceptions is USAI and VANNINI (2005), who confirm market segmentation with respect to (rather large) Italian regions. Due to the argument that diverse interest rate levels across regions will prevail also in integrated markets because of differences in risk and transaction costs, they test whether marginal movements of rates over time are dissimilar. As in the case of USAI and VANNINI (2005), the approach pursued in this paper for the Austrian example is to assess the adequacy of a pre-set market delineation. Since the applied data are cross-sectional, segmentation is examined in space while controlling for several regional characteristics.

A final aspect to be considered is that the spatial distribution of financial markets and institutions has been and, further on, is determined and affected by the interests of several groups of actors. Especially regional banks operate in an environment where their goals are entangled with local economic and political interests. ${ }^{9}$ VERDIER (2000), for example, describes the involved mutual dependencies. The local economy hinges on credit from 
local banks, which seek for possible political protection from competitive threats. Local governments, in turn, are interested in a prospering local economy that supports their financial and political prospects. These interests therefore explain both the existing structures in many local banking systems (public influence through ownership, market foreclosure) as well as an innate resistance to structural changes that potentially lead to a drain of resources from the periphery to financial centers. According to VERDIER (2000), political and financial decentralization go hand in hand and, up to now, the participants in and the proponents of such constellations have successfully held their ground in times of deregulation and increased competition. DEEG and LÜTZ (2000), as well as VERDIER and BREEN (2001), however, argue that the balance of power increasingly shifts toward financial and political centers.

\section{DATA, VARIABLES AND EMPIRICAL STRATEGY}

For statistical and other purposes, the Austrian banks are partitioned into "sectors" according to their legal form and their affiliation with different associations, respectively. The group of joint-stock banks mainly consists of commercial banks and wealth managers. Most Austrian savings banks are legal entities under private law, founded by municipalities or associations. Their regional market segregation was formally abolished in the 1970 s, though a non-profit orientation is still present in banks' statutes and self-conception. Two groups of cooperative banks - Raiffeisen and "Volksbanken" - exist in Austria. As in Germany, "cooperative banks follow the non-profit mission to support the business of their members" (CONRAD et al., 2009), which are also their owners. State-owned mortgage banks make up the final bank type considered. ${ }^{10}$

Distinct institutions (from different sectors) exhibit special features which presumably cause regional bank behavior and performance to vary according to the geographical dispersion of these entities. ${ }^{11}$ First, many banks are protected from being taken over because they are publicly owned (most savings banks and the state mortgage banks) or 
owned by cooperative members, which constitutes an obstacle to entry. Second, savings banks as well as credit cooperatives still operate mainly in designated regions and rarely invade markets of other institutions from the same sector. A third issue is the multi-tier structure of the savings banks and cooperatives sectors consisting of two or three ${ }^{12}$ layers of institutions, which each are connected via a network structure with internal capital markets and mutual assistance arrangements. ${ }^{13}$

In the following assessment, data on the branch location and from the financial statements of 749 Austrian banks are used. ${ }^{14}$ Most of the examined institutions are universal banks, and many are small regional institutions. 190 of them are single-branch banks and further 50 operate only within one municipality (see Table 1, also for the sectoral division and other information).

\section{[INSERT TABLE 1]}

The unit of observation in this study, however, is the administrative district, and all information is converted to this level. It is thereby assumed that the district (as often done for German districts or US counties) represents a suitable market delineation in terms of both geographical outreach and relevant competitors. About three quarters of the sampled banks do not entertain subsidiaries outside the district in which the main office is located (see HAHN, 2008, for a similar figure), and of those that do, several may operate near district borders. The remaining fourth are what the literature would term multi-market banks (MMB). On average, an Austrian district spans an area of 693 square kilometers, ${ }^{15}$ and has 69,052 inhabitants as well as 40.9 bank offices. By EU and US standards, both Austria and Germany are considered heavily banked (HACKETHAL, 2004; CONRAD et al., 2009). With 0.61 bank offices per 1000 capita in 2008, Austria ranks 7th among the EU 27 countries, Germany is two positions behind. ${ }^{16}$ The German bank penetration (0.5), however, roughly equals the EU 27 average.

In the following, the demographic bank outreach within 99 Austrian districts (the 23 Viennese districts are treated as one entity) shall be related to regional and structural 
factors. The first of these is the district classification of PALME (1995), which differentiates according to the prevailing economic structure. PALME (1995) allocates the Austrian districts into 9 groups, from metropolitan to touristic periphery (see Table 2, which also contains the numeration used by HAHN, 2008). Based on this division, HAHN (2008) aggregates to human capital intensive, physical capital intensive, and rural regions. In general, one would presume that the less industrialized and the peripheral districts (Palme groups 6, 8 and 9, classified as rural) are the less prosperous ones. By matching economic structure with regional product per capita in 2006 (which is, however, only available for the 35 Austrian NUTS 3 areas), it can be observed that several suburban and medium-sized town districts, but also some districts in intensive industrial and touristic regions, are located in NUTS 3 regions with a relatively low income level. As an additional measure, the real growth rate of regional income from 1998 to 2006 is applied. Table 2 presents mean values of regional income and growth, as well as of population density, for each Palme group. These variables also represent often-used proxies for the demand for banking services and also Table 2 shows that the information they convey does not completely overlap. A depiction of the geographical income dispersion is provided by Figure 1 . Information on data sources, definitions and dimensions regarding all the measures and variables used in this study is provided in the appendix.

[INSERT TABLE 2]

\section{[INSERT FIGURE 1]}

Among the district-level measures related to market structure there is the presence of out-of-market banks (OMB), measured by the share of branches of banks with their main location outside the particular district in the total number of bank offices. Regional Herfindahl-Hirschman indices $(\mathrm{HHI}$, sums of squared market shares) are used to measure market concentration. Since financial figures are not available at the subsidiary level, the information on the branch distribution is used to calculate these indices, as it is regularly done with regional data (FISCHER and PFEIL, 2004; FISCHER, 2005; DEGRYSE and ONGENA, 
2005; Fischer and HempelL, 2006; Coccorese, 2008, 2009; FERnÁNDEZ DE GuevarA and MAUDOS, 2009). Based on calculations for local US markets, FISCHER (2005) argues that $\mathrm{HHI}$ computed on branches are a reasonable approximation of "common" Herfindahl indices based on market shares in assets or deposits. According to "widely accepted cutoffs" (DEGRYSE and ONGENA, 2008), a market with an HHI below 0.10 is typically rated competitive, and $\mathrm{HHI}$ values higher than 0.18 indicate highly concentrated markets (DEGRYSE and ONGENA, 2005). Furthermore, 0.18 is the threshold US regulators use in merger assessments (FERNÁNDEZ DE GUEVARA and MAUDOS, 2009). However, as withingroup competition is low for savings banks and credit cooperatives, these sectors may be treated as single entities (HACKETHAL, 2004). Concentration measures as they are commonly calculated therefore may provide a distorted image of the effective intensity of competition (Schnabel and HaKenes, 2006; ReHM, 2008). A variant of the HHI is thus calculated as well, assuming that the respective sectors consist of one bank only.

Further measures - indicators of profitability, efficiency, competitive behavior and financial development, as well as interest rates - are calculated by using bank-individual financial figures (for 2006). Thereby, the necessary base data (profits, for example) first is aggregated to the district level and afterwards, the respective indicator is calculated. These measures, however, only apply to the incumbent banks as data for the out-of-market banks' branches are not available.

The return on assets (ROA) is used as an indicator of market profitability. Interest rates are approximated by average ex-post rates, calculated by dividing the interest income (expenses) by all interest-afflicted assets (liabilities). Bank efficiency is measured by "scores" obtained from a Data Envelopment Analysis (DEA) of bank outputs and inputs. These are relative measures of technical efficiency with a principle upper bound of one for the "best-practice districts." The less efficient, the lower the assigned value (see Appendix B for further calculation details). Data for 2006 are used to obtain estimates of the efficient frontier and the relative positions of the individual districts. 
The effective degree of bank competition within districts is measured by the so-called H-statistic (PANZAR and Rosse, 1987), that is based on the extent to which changes in input prices are reflected in equilibrium revenues. Its values have an upper limit of one, and lower values point to less competitive behavior. Lerner indices (markups of price over marginal cost) are applied as a second competition measure. A lower competition intensity is assumed to be reflected in higher markups. More details on the calculation of both $H$ and Lerner indices are to be found in Appendix B.

A common measure of financial depth is the ratio of bank credit to economic activity. As, however, gross regional product does not refer to districts, regional financial development (and with it the development of the banks' economic and structural environment) is depicted by the so-called intermediation ratio, the relation of total loans to total deposits. It can be presumed that the structural weaknesses of rural regions with low local prosperity are reflected in the banks' balance sheets by a more or less severe incongruity between deposits and loans.

Descriptive statistics for the applied variables at the district level, including population density, ${ }^{17}$ are presented in Table 3 . The mean value of the demographic bank office penetration across districts is 0.71 , which corresponds to 1,408 inhabitants per branch. ${ }^{18}$ Figure 2 presents an illustration of branch density across the Austrian territory. It can be observed that there are many banks per 1000 capita in some districts at the national border, in some medium-sized towns and alp districts, while bank penetration tends to be lower in larger towns and their suburbs. Differences across districts can be considered quite large, which is also true with respect to the distribution of banks from differenct sectors (see Table 3 as well).

\section{[INSERT TABLE 3]}

\section{[INSERT FIGURE 2]}

Obviously, Raiffeisen credit cooperatives dominate the local banking markets in Austria. In Germany, for comparison, this role is played by savings banks (FISCHER, 2005), 
although CONRAD et al. (2009) report that the demographic penetration of savings banks and credit cooperatives is almost equal ( 0.22 and 0.21 banks per 1000 capita for the average district). From sectoral versions of Figure 2 (which are not shown), it can be observed that the Raiffeisen banks are most evenly distributed across the country, followed by savings banks. ${ }^{19}$ Commercial and state mortgage banks are present not at all in 14 and, respectively, 32 districts. There is no office of a savings bank (Volksbank) in four (three) districts, while there is at least one Raiffeisen subsidiary in each domain. Compared to their "own" average density, joint-stock and state mortgage banks are relatively more present in towns, while the reverse is true for Raiffeisen credit cooperatives.

The following empirical strategy is pursued in the subsequent examination of local Austrian banking markets. At first, a descriptive analysis of demographic bank office density and local market structures, their interrelations and the role of the demographic and economic environment is conducted. Then, district-level measures of bank conduct and performance are added to the exposition and regression methods are applied in Section 5 to analyze the determinants of interest rate levels, profits, efficiency and competitive behavior in local markets. These variables are related to bank penetration, market structure and environmental variables in this process, and further possibly influental factors which are derived from the literature. Finally, similar models are estimated for bank office density and local economic growth as dependent variables.

An important aspect in the empirical analysis of regional data is to consider possible spatial dependencies. A spatial interaction of regional units might, for example, result from spillover effects if markets are not strictly delineated by district borders. If this is the case, the variables to be explained in the regression models are correlated for neighboring districts. Unless this correlation can be attributed to the geographic characteristics of the independent variables, OLS estimates may be biased and/or inefficient (see WARD and GLEDITSCH, 2008, or ANSELIN, 2009, also for an introduction to spatial regression models). 
The information on relative location and the scope of spatial dependencies is introduced via a so-called spatial weights matrix W. In this paper, a spatial weights matrix based on (first-order) contiguity is applied, with $w_{i j}=1$ when districts $i$ and $j$ are geographical neighbors (when they share a common border), and zero otherwise. Possible spillovers therefore are assumed to originate only in "surrounding" districts, which are equally weighted. A distance-based weights matrix ${ }^{20}$ was also employed for robustness purposes, but the results in Section 5 are rather unaffected by the type of $\mathbf{W}$ used.

Spatial statistics based on the above contiguity coding are used to assess how similar neighboring observations are on some attribute. Therefore, $\mathbf{W}$ typically is rowstandardized so that the weights of the neighbors sum up to one. Thus, the correlation of, for example, bank profitability with the average profitability in contiguous districts can be easily calculated. The corresponding global measure for the entire sample is Moran's /, which can also be decomposed into correlations for each regional unit - the so-called local indicators of spatial association (LISA; see ANSELIN, 1995).

After the examination of spatial clustering in banking variables, the regression models applied in Section 5 are tested for spatial dependencies after accounting for covariates that probably are correlated in space as well. $L M$ type tests are applied to test the null hypothesis of spatial randomness in these regressions, and to decide whether the better way to model geographic clustering is throuh a spatial lag or spatial error model (see ANSELIN, 2009). The spatial lag model

(1) $y=\rho \mathbf{W} y+\mathbf{X} \beta+\varepsilon$

includes a term that considers a dependence of attribute y on the (average) value of the dependent variable in neighboring regions, while the spatial error model

(2) $y=\mathbf{X} \beta+\lambda \mathbf{W} \xi+\varepsilon$

allows for a part of the error term to be correlated across regions, which may be due to, for example, unobserved spatial effects. Both models are estimated by Maximum Likelihood. Although the choice of the model should be theory-guided, we follow ANSELIN (2009), who 
suggests to employ test outcomes in the selection process. If the spatial lag model applies, OLS estimates are biased, whereas in the case of error dependence the main concern is their inefficiency (WARD and GLEDITSCH, 2008; ANSELIN, 2009).

\section{BANK OFFICE OUTREACH AND LOCAL MARKET STRUCTURE}

The analysis of local Austrian banking markets commences with an assessment of the simple relations between bank office penetration, market structure, as well as the demographic and economic environment. Compatible with the presumption that more banks are located in regions with a higher population and a therefore higher demand for banking services, the correlation between the number of bank offices and population density is $0.76 .^{21}$ The increase in bank branches with population, however, is underproportional - bank office penetration is lower in more densely populated areas. ${ }^{22}$ Similar relations emerge with income per capita, and also Table 2 reveals that bank penetration is comparatively higher in intensive touristic and rural regions. ${ }^{23}$ Surprisingly, demographic branch penetration is uncorrelated with income growth. The above results reemerge with the regression analysis in Section 5.5 and are thus found robust to the inclusion of further covariates in explaining bank office density.

Across districts, the sectoral bank densities are quite related for commercial and state mortgage banks, as well as for savings banks and Raiffeisen credit cooperatives. For Eastern Germany, for example, WENGLER (2006) finds that cooperatives and savings banks follow similar branch strategies. From our data it can also be observed that the latter groups are more dense where joint-stock banks are underrepresented. Significant correlations with population density emerge for the commercial banks (0.51), as well as for savings and Raiffeisen banks $(-0.20$ and -0.50$)$. This resembles the evidence for Germany that the penetration of private banks is highest in larger cities and lowest in the least densely populated areas, as reported by CONRAD et al. (2009). A difference to their results, however, is that savings banks and, above all, Raiffeisen banks are increasingly present in 
less populated areas (see also Section 5.5). The joint-stock banks are significantly more represented where income per capita is higher, whereas the demographic office density for Raiffeisen credit cooperatives is negatively related to regional product. Compatibly, commercial banks are found to dominate the cities - more strongly than in Germany (see FISCHER and PFEIL, 2004; CONRAD et al., 2009), but are much less present elsewhere. Moreover, a significantly increased penetration of Raiffeisen credit cooperatives in rural areas is apparent. In a nutshell, it does not turn out that poorer, less populated and less industrialized regions are tended worse with banking services. While profit-maximizing commercial banks are underrepresented in less populated and low-income regions (which is the case for Germany as well, as reported by WENGLER, 2006, and CONRAD et al., 2009), other groups of regional banks, especially credit cooperatives, are even increasingly present in these areas.

Turning to the market structure variables, it emerges that out-of-market banks' (OMB) activity ranges between zero and 87.5 percent. The average share of OMB branches in bank offices across districts is about $37 \%, 19$ districts show up with a value of more than $50 \%$. As indicated above, the market delineation referring to the regional principle strongly rests on the observation that only $26 \%$ of all banks are multi-market banks. From Table 1 , however, it can be inferred that the share of multi-district banks, as well as the share of out-of-market branches, is quite high for all bank types except for the Raiffeisen credit cooperatives. Large parts of the Austrian banking sector (the savings banks and the Volksbanken) are, therefore, not so locally oriented as it may be presumed. Additionally, the regionality of joint-stock banks is overrepresented as many of those are single-branch banks located in Vienna. Based on these figures, the perception that the district is a suitable market definition (HAHN, 2008) is somewhat questionable.

Bank concentration, as measured by the $\mathrm{HHI}$ based on the branching structure, is 0.16 on average across the Austrian districts. By a comparison to similar indicators for Germany (FISCHER and PFEIL, 2004; FISCHER, 2005), local Austrian banking markets 
appear to be somewhat less concentrated. ${ }^{24}$ In 2006, 15 districts exhibit an $\mathrm{HHI}$ value of below 0.10 (and thus may be rated competitive), while 23 of them are highly concentrated (with an $\mathrm{HHI}$ larger than 0.18 ). An $\mathrm{HHI}$ of 1 emerges for a city district with only one bank office, the highest value apart from that is 0.5 . The $\mathrm{HHI}$ is not correlated with population density and income growth, but negatively with regional product per capita. Bank concentration is especially low in city and suburban districts, as well as in intensive industrial and touristic regions. As in Germany (FISCHER, 2005), there is no clear-cut ruralurban pattern, ${ }^{25}$ but we can observe a significant difference between the $\mathrm{HHI}$ in physical capital intensive regions (Palme 4 and 5) and the rural areas (Palme 6, 8 and 9), with the latter being more concentrated.

As argued above, banks from several sectors do not, intra-sectorally, enter each other's designated market territory, so the $\mathrm{HHI}$ as it is commonly calculated gives a distorted picture of competition. It is apparent from Table 3 that the "consolidated" $\mathrm{HHI}$ is much higher with an average of 0.38 across the 99 districts. Unsurprisingly as well, there is a much higher diversion of concentration between towns (low concentration) and rural areas, with the highest $\mathrm{HHI}$ values emerging for markets which are near the national border. This is consistent with the observation that it is mainly the Raiffeisen credit cooperatives which are serving the far reaches. While the correlation between this $\mathrm{HHI}$ and the density of Raiffeisen banks is positive, it is significantly negative for commercial and state mortgage banks, and the Volksbanken as well. As much of the out-of-market activity comes from these three sectors, adapted concentration is found lower with higher OMB penetration.

Concerning regional financial development, districts with a high population density and in high income regions also show up with large values for the intermediation ratio, but the latter does not significantly differ between fast-growing and almost stagnating regions. The highest ratios of loans to deposits (of incumbent banks) are observable for city districts, followed by Vienna. Especially low is this ratio for suburban districts (Palme 2), as 
well as for the rural areas. Commercial and state mortgage banks are significantly more present in more developed banking markets, whereas the reverse is true for Raiffeisen cooperatives. It seems also noticeable that the intermediation ratio is higher for less concentrated markets, though the correlation with the un-consolidated $\mathrm{HHI}$ is significant only at the $10 \%$ level. Other relations to variables discussed so far (OMB penetration, for instance) are not present.

\section{CONDUCT, BEHAVIOR AND OUTREACH IN LOCAL BANKING MARKETS}

In this section, we will add several measures of bank conduct and behavior to the exposition, which have been thoroughly studied by the empirical literature, though not necessarily in the regional context. These variables have already been described in Section 3 and corresponding descriptive statistics can be found in Table 3 . Prior to estimating multivariate regression models for the most important measures (including demographic bank density and regional growth as well), spatial dependencies in these variables are examined. Table 4 reports the results on Moran's / for interest rates and profits, efficiency scores, competitive behavior, bank office density and regional income growth, based on the contiguity matrix described in Section 3 . Inference is based on a normalization resulting in $z$-scores, and significant spatial clustering is confirmed, for example, at the $5 \%$ level if the associated standard normal $z$-value is higher than 1.64 (for a one-sided alternative hypothesis).

\section{[INSERT TABLE 4]}

The results on Moran's / in Table 4 suggest that several variables exhibit significant positive spatial clustering, so that, generally, the attribute in location $i$ is positively correlated with its average in neigboring districts. For some of these measures, there might be a straightforward explanation for the observed dependence. For the efficiency scores, it may be due to low overall variation, while income growth is quite necessarily clustered as it is not measured at the district level. Bank office densities are probably correlated because 
of the sectoral office location policies described above. The most intense clustering occurs with loan (asset) pricing, so a closer look is taken in form of local measures.

Figure 3 shows how many and which districts are responsible for the observed crossdistrict correlation in lending rates. Different shades of grey are used to mark $z$-scores for the LISA statistics in steps of 0.5 between the range from -0.5 to 3 (with open end invervals and darker shades representing higher $z$-values). It turns out that the deviation from spatial randomness is only significant for 12 of the 99 districts, which are confined to four areas (the dark spots in Figure 3). Average rates on interest-earning assets are, for example, rather high in many districts in Carinthia (the area in the south), while their level is below average for districts near Liechtenstein and Switzerland (the western cluster). For the rest of the country, the spatial association in interest rates calculated at the district level is very low. As the few "hot spots" just describe are likely connected to special factors, it can be concluded for lending rates (and, in consequence, also for bank profits) that banking markets in Austria are indeed fragmented to a large extent if pre-defined by local administrative borders.

\section{[INSERT FIGURE 3]}

Table 4 also presents spatial diagnostics for regression models in which the discussed attributes make up the dependent variables (the covariates are described in the following and can be inferred from Table 5 yet). $L M$ type tests are applied for model choice, following ANSELIN (2009) who states that the proper specification "is most likely the one with the largest significant $L M$ test statistic value." Robust forms of these tests are to be applied if spatial dependence is detected, as the tests affect each other in this case (see also ANSELIN, 2009). The test outcomes indicate that a spatial lag model (SLM) is the proper specification for the lending rate and returns equations. For deposit rates and Lerner indices, spatial dependence in the error term is indicated at the $10 \%$ level. Results from spatial error models (SEM) shall be reported in these cases, although they are quite similar to those obtained by OLS regression. 


\subsection{Retail Interest Rates}

The main factor the empirical literature examines in connection with bank retail rates is market concentration, often with the presumption that concentration is a proxy for the competitive conditions prevalent in the market. Lending rates are an important part in the causal chain that is often termed the "traditional market power view" of the relation between bank competition and economic activity (CARBó-VALVERDE et al., 2009). Less competition between banks (increased concentration) thereby is supposed to lead to higher lending rates and, via effects on both loan demand and supply, to lower economic growth (Claessens and Laeven, 2005; BIKKER, SPieRDiJK and FinNie, 2007; FeRnández de Guevara and Maudos, 2009). Degryse and Ongena (2008) argue that there is ample evidence on the positive impact of concentration on loan rates. With respect to deposit rates, Degryse and ONGeNA (2008) state that the literature (an example is HeITFIELD and PRAGER, 2004) tends to find that saving rates decrease with higher (local) concentration.

Empirical results for German banking markets as well suggest a connection of concentration and interest rates. FISCHER (2005), for example, finds that rates on loans to small enterprises are higher and deposit rates are lower when the local market (the district) is more concentrated. Less local competition (indicated by higher Lerner indices) has the same effects according to FISCHER and HEMPELL (2006).

Another prominent influence on retail rates is the bank structure within a market. In most cases, it boils down to how the retail rate level or the rates set by incumbent (small, local) banks are affected by an increased penetration of out-of-market or multi-market banks, which are presumed rather large institutions. Both DEGRYSE and ONGENA (2008) and PARK and PENNACCHI (2009) argue that loan rates are lower in markets with an increased presence of or competition by large multi-market banks, based on the empiricial evidence provided by BERGER, ROSEN and UDELL (2007). On the other hand, multi-market banks do not compete with the incumbents for deposits despite operating and funding cost 
advantages. This makes it possible also for the small local banks to lower their savings rates. Hannan and Prager (2004), Berger et al. (2007) as well as PARK and Pennacchi (2009) provide evidence in this respect.

Loan rates are also found to be higher with increased proximity to borrowers (Petersen and Rajan, 2002; Degryse and OngenA, 2005), but lower if competing banks are relatively less distant (DEGRYSE and OngENA, 2005). RICHARDS, ACHARYA and KAGAN (2008), however, present evidence compatible with tacit collusion in local US banking markets. They argue that banks seek to locate themselves where the demand for banking services is high - which thus leads to a high bank density there, but do not fiercely compete with each other. Optimally, all of them profit from the high level of demand and do not have the need to, for example, underbid each other with respect to loan rates. Finally, banks in rural areas may be able to extract rents via lower saving rates due to an inert deposit base. According to HACKETHAL (2004), this may be true for German savings banks.

Due to data limitations, retail rates are proxied by the average ex-post rates on interest-afflicted assets and liabilities of incumbent banks. The rate on interest-earning assets (henceforth termed as loan rate) ranges between 3.21 and 6.09 across districts, and deposit rates (average rates on interest-bearing liabilities) show even more variation than lending rates (see Table 3). While loan rates are relatively higher in rural districts, saving rates in both physical capital intensive as well as rural regions are significantly lower compared to those in urban areas. Several bank office densities are correlated with the district-wise saving rates: those of commercial and state mortgage banks positively, that of Raiffeisen banks negatively.

For a regression analysis of lending rates, the following variables are considered. First, we apply the bank office density in the district, also as a measure of competition as it can be assumed that "the number of banks in the market is typically inversely related to the distance between the lender and the (closest) competing banks" (DEGRYSE and ONGENA, 2005). Ignoring the possibility of tacit collusion, the expected influence is negative. 
Regional product and income growth depict the demand for banking services, while population density is also understood as a measure of the proximity of banks to their customers. Moreover, we add financial development, bank efficiency, concentration, both competition measures (as the $H$-statistics and Lerner indices are not significantly correlated), and the share of bank offices that come from out of the market. Dummy variables for additional non-modelled differences between the physical capital intensive and the rural regions with respect to urban areas are taken into account as well.

The regression results (from a spatial lag regression with robust standard errors) are reported in Table 5 under the header $L R$ (lending rate). The relation of bank office density with the loan rate is negative - consistent with the argumentation that if the former captures the proximity to rivals, more competition results in lower lending rates - but not significant at conventional levels. Loan rates are lower in regions with higher income growth (or vice versa), while there is no significant relation to population density, regional product, the intermediation ratio and bank efficiency. Given several competition measures, concentration (the $\mathrm{HHI}$ ) is insignificant as well. While this is also the case for the Lerner index, competitive behavior as depicted by $\mathrm{H}$-statistics is, surprisingly, positively related to the lending rate. This result may be connected to the bank office density already (or also) capturing the degree of competition in the market, but might be related to specific characteristics of $H$ as well. For one, the $H$-statistics are calculated from data over a longer period, while the interest rates are for one specific year. Additionally, $H$ measures the reaction of revenues to changes in the input prices. A fast reaction, the otherwise presumed behavior under strong competition, is not against higher lending rates if times of input price increases prevail. It may also be true that the causality is reverse - that markets that allow for high rates are increasingly contested. No effect is found for the presence of out-of-market banks on the rates of incumbent banks. ${ }^{26}$ However, loan rates are higher in rural districts, which may be due to a higher risk of the loan portfolio because of less diversification possibilities. From additional regressions with the bank density replaced by 
each of the sectoral office penetrations we do not observe any significant relations of these variables to the lending rate level.

Results for deposit rates $(D R)$ with the same explanatory variables applied are also to be found in Table 5. Saving rates are found lower in more concentrated regional markets (at the $10 \%$ level), while there is no relation confirmed to the competition variables. Moreover, it does not seem that there is an urban-rural pattern remaining and that deposit rates vary with the importance of out-of-market banks. The most striking result in the respective regression is that saving rates are higher in districts with a higher ratio of loans to deposits. As the intermediation ratio is related to economic prosperity and structural factors, the result might be a reflection of an increased anxiety for deposit acquisition in such regions.

\section{[INSERT TABLE 5]}

\subsection{Profitability}

Referring to the relations of concentration, competition and bank type distribution on retail rates, PARK and PENNACCHI (2009) argue that the effect on profits depends on the relative magnitude of the effects on the rates. Therefore, many of the arguments presented in the previous section can be applied also with respect to the return on assets. There is, however, additional literature that directly refers to bank profitability rather than to the rates they charge. Several studies report that small (single-market, rural) banks are more profitable in case of a greater presence of large outside rivals (e.g. PILLOFF, 1999; HANNAN and PRAGER, 2009). The frequently given explanation is the one mentioned above about the cost advantages of OMB transferring to a lower level of deposit rates for the whole local market. Another reason for an absence of effective rivalry might be that banks from outside the market specialize in different products and therefore attract a different clientele (COHEN and MAZZEO, 2007). The low general level of bank profitabity in Austria as well as in Germany is often ascribed to a high degree of competition (for respective insinuations 
and references see HAHN, 2008, or CONRAD et al., 2009). If this is true, such an effect should also be observable at the regional level, given that banking markets are actually local.

The district-wise ROA is lowest in cities and high especially in intensive touristic areas and in the industrial periphery. Generally, pairwise correlations of the ROA with the other variables are much in accordance with the effects found in the regression analysis (see Table 5). Bank profits do not vary across the districts' income level, economic growth and bank office concentration, but are significantly lower with higher intermediation ratios. As with the interest rates before, the OMB penetration has no effect as well. Confirming a well-known relation from the literature (e.g. VANDER VENNET, 2002), bank efficiency is a main determinant of profitability. The ROA is positively related to the Lerner index, but to the $H$-statistic as well which seems (as discussed before) somewhat odd at the outset. From auxiliary regressions with bank office penetration alternately replaced by the sectoral ones, it can be inferred that returns are higher in districts where state mortgage banks are dense. As they make up the least profitable Austrian banking group (and profits are for incumbents only), it can be concluded that their branching policy is one of entering profitable markets. This is much less (and insignificantly) the case for the commercial banks, but the evidence on such a behavior might be obscured by several of these banks being single-market banks located in Vienna.

\subsection{Efficiency}

The determinants of bank efficiency as identifiable from the respective literature are, more or less, the ones also applied with interest rates and profitability. A profit measure appears in almost every study, but is represented by the Lerner index in our case as the ROA and the markup are highly correlated. Efficiency should be connected to the demand for banking services as banks "that primarily operate in richer districts face an external environment which is likely to foster banking efficiency" (HAHN, 2007b). HAHN (2007b) also 
finds that, given income, bank-individual technical efficiency in Austria is relatively higher in urban areas and densely populated districts. The structure of the market is proposed to affect efficiency (HAUNER, 2005; PASIOURAS, 2008), and demographic branch density is used as a measure of the access to banking services in PASIOURAS (2008). In the crosscountry study of WEILL (2004), efficiency and competition are found to be negatively related. He ascribes this result to reverse causality, arguing along the efficient-structure hypothesis: more efficient banks gain market shares which leads to reduced competition. WEILL (2004) additionally reports an increased bank efficiency with higher GDP per capita and larger intermediation ratios. He interprets high intermediation ratios as indicating a reduced need of deposits to produce loans, which then is less costly. Using Lerner indices, MAUdOS and FERNÁNDEZ DE GUEVARA (2007) confirm the negative relation of competition and efficiency that WEILL (2004) reported with $H$-statistics applied. Referring to the focus on profit-maximization, it could be presumed that savings banks and cooperatives turn out less efficient. No differences in efficiency across bank types are found by CASU and MOLYNEUX (2003), but HAUNER (2005) observes that savings banks exhibit relatively lower efficiency levels in Germany and Austria.

The regression results for Austrian regions in Table 5 also include OMB activity as a factor describing the operating environment which, however, is not significant. This is also evident for income and economic growth, and there are no regional patterns remaining for the respective dummies to be significant. ${ }^{27}$ Though the dispersion of DEA efficiency scores across districts is very low (see Table 3), some of the proposed factors help to explain these differences. While branch concentration is not among these factors, the banking sector is more efficient in markets that are more densely populated both by inhabitants and banks. Bank office penetration again may convey the effect of an increased proximity to rivals, in line with the fact that there is no explanatory power left for $H$ as a competition measure. Both the positive relation of efficiency to the Lerner index (as in MAUDOS and FERNÁNDEZ DE GUEVARA, 2007) as well as to the intermediation ratio (as in WEILL, 2004) 
can be confirmed with respect to regional data for Austria. Instead of being a strict competition measure, however, high markups may - as well as increased efficiency scores do - be indicating superior cost management. The effect of the intermediation ratio, on the other hand, might reflect a positive influence of economic development and prosperity. Finally, in alternative regressions, sectoral bank penetration is positively significant with respect to Raiffeisen credit cooperatives and state mortgage banks.

\subsection{Competitive Behavior}

While competitive behavior was commonly deduced from concentration measures in the past, many more recent studies have failed to observe a significant relation between concentration and competition in banking markets (CLAESSENS and LAEVEN, 2004; CASU and GiRARdone, 2006; FernÁNDEZ de GuevarA et al., 2005; BikKER et al., 2007; CARBó VALVERdE and RodríGuez FERnÁNDEZ, 2007; MAUdos and FERNÁNDEZ dE GueVARA, 2007). As, however, lower competition is found with more concentrated markets in the crosscountry applications of BIKKER and GROENEVELD (2000) and BIKKER and HAAF (2002), FISCHER and HEMPELL (2006) and COCCORESE (2008) also report such a connection at the regional level for Germany and Italy, respectively. On the other hand, several studies (e.g. SHAFFER, 2004; COCCORESE, 2009) observe that also in relatively concentrated local markets, banks behave nearly competitively.

No relation of competition and income levels is found by BIKKER et al. (2007) and COCCORESE (2008), but disposable income per capita positively affects local competition in Germany as reported by FISCHER and HEMPELL (2006). An increased bank (branch) density goes along with more competition according to the results of CASU and GIRARDONE (2006) and Coccorese (2008). CocCORESE (2008) also finds bank rivalry to increase with regional financial development (measured by the ratio of loans to GDP), and the intermediation ratio positively affects competition in CASU and GIRARDONE (2006). The latter also report a negative connection with efficiency, as WEILL (2004) and MAUDOS and 
FERNÁNDEZ DE GUEVARA (2007) found for the reverse causal setting. Rural banks should be able to extract rents due to market power from isolation according to RICHARDS et al. (2008).

Since solely the intermediation ratio (negatively) seems to be connected to the $H$ statistics, we only report the results for the district-wise Lerner indices in Table 5. As in the literature mentioned above, an increased bank office density indicates more competition and therefore lower markups. The same is true for population density, but neither regional income and its growth, nor the intermediation ratio seem influental. Banking markets with more efficient institutions also are those with higher Lerner indices, which confirms previous results from other studies as well. Though not significant, the effect of concentration on markups, remarkably, has a negative sign, which would imply a positive concentration-competition link. Such a result is actually reported by ANGELINI and Cetorelli (2003), who study geographically distinct, subnational banking markets in Italy. They argue that this is a result of reverse causality with banks reacting to an increased market contestability by consolidation and restructuring.

Rural banks indeed seem to extract rents from spatial market power as the rural districts exhibit significantly higher Lerner indices (at the $10 \%$ level). From the raw data it can be observed that markups are lowest in Vienna, but very high in extensive industrial regions and the touristic periphery. Again, the presence of out-of-market banks has no explanatory power for the dependent variable. Furthermore, there are no effects found in auxiliary regressions related to the sectoral bank office penetration variables.

\subsection{Bank Office Density}

A final regression shall relate the demographic bank office density to the variables also applied in the previous sections, with the results being reported in the last column of Table 5. As a crude reference, CONRAD et al. (2009) regress the branch penetration of savings 
and cooperative banks in German districts on several variables, including GDP per capita, population density and a competition indicator.

From our results it emerges that the number of bank offices per 1000 capita is lower in more densely populated as well as in high-income areas, and higher in rural regions (which is in line with the descriptive analysis in Section 4). The relations to efficiency and markups reported above turn out to be observable in this specification as well, but no other factor is significant. From similar regression with the sectoral branch densities as alternating dependent variables (which are not presented in tabular form), we never find a positive relation to regional income as reported by CONRAD et al. (2009). The negative relation to population density is only present for savings banks and Raiffeisen credit cooperatives (which is in line with the results for Germany), while joint-stock banks are increasingly present in more densely populated areas (see also Section 4). It's the growing regions where commercial and state mortgage banks are more dense. There also is a significant urban-rural decline in the presence of these banking groups, while the reverse is true for savings banks and Raiffeisen cooperatives.

The relations of the sectoral branch densities to concentration and OMB presence turn out as expected. Concentration is lower and OMB presence is higher where there are more branches per 1000 capita of joint-stock banks and state mortgage banks. Raiffeisen banks are less dense with an increased branch penetration from outside the market. Referring to the remaining variables it has to be kept in mind that they are constructed from the incumbents' data only. The markups calculated in this manner are lower (indicating a more contested market) where commercial and Raiffeisen banks are dense, which is somewhat surprising. A high (low) pentration of state mortgage (Raiffeisen) banks seems typical for markets with a high intermediation ratio. This is in line with the prior observation that the credit cooperatives take on the role to serve less developed markets in Austria. Both the state mortgage and the Raiffeisen banks are significantly more dense in districts where the incumbents exhibit a higher efficiency level. As the branches of the former 
banking group are often from outside the district while the latter rarely leave their home market, it may be concluded that state mortgage banks actively seek "efficient districts," while the Raiffeisen banks aid to form these.

\subsection{Regional Finance and Growth}

As argued before, the regional principle pursued by several banking groups leads to spatially segmented financial activity. This fragmentation hinders capital mobility across regions, thereby forestalling an alignment of interest rates and credit availability. In this case, the local financial development plays an essential role for regional prosperity (Klagge and Martin, 2005; Fernández de Guevara and Maudos, 2009). Guiso et al. (2004), for example, find evidence for such an effect even though capital may move frictionlessly between the examined Italian provinces. Another strand of the literature argues that the efficiency of the regional banking system and the presence of distinct banks should improve local economic development. Related to the German case, this attribute is frequently argued especially for savings (public) banks (GÄRTNER, 2009a; SCHMIDT, 2009; HAKENES et al., 2009; HAKENES and SCHNABEL, 2010). Such small localized banks are presumed to prevent a capital drain from poor to rich regions to shield small local business from credit rationing (HAKENES et al., 2009). While HAKENES et al. (2009) also empirically support this for efficient savings banks, CONRAD et al. (2009) state that, in principle, the same should apply to cooperative banks as these mainly lend to their (local) members. USAI and VANNINI (2005) report regional growth in Italy being associated to the presence of cooperative banks, BERGER, HASAN and KLAPPER (2004b) present crosscountry evidence that is in favor of faster GDP growth where the market share of small, domestic community banks is higher in local markets.

Pertaining to other banking-related influences on growth, there is an intense academic debate about the effects of bank competition and its measurement (see, for example, CARBÓ-VALVERDE et al., 2009). Regional studies, however, are scarce also in this 
respect. FERnÁNDEZ DE GueVARA and MAUdos (2009), for example, find an U-shaped relation between the Lerner index and growth for Spanish regions. They conclude that moderate market power can lead to higher growth as it may improve the financing possibilities of informationally opaque firms. While local banking concentration is found insignificant in Fernández de Guevara and MAudos (2009), Collender and Shaffer (2003) observe that regional income growth in the USA is lower in more concentrated markets. The latter also argue that a higher bank office penetration is associated with faster growth and that the increased display of nonlocal banks (especially through mergers and acquisitions) is not detrimental to local economic growth in rural areas. Regional data from eleven European countries are used to study the effect of bank efficiency by HASAN et al. (2009). They report that the efficiency effect on regional growth is larger than the one propagated through "traditional" measures of financial development.

From Table 3 it can be seen that there is considerable variation in local interest rate levels as well as growth rates. However, regressions in a similar fashion to those conducted in the previous sections reveal that almost none of the banking-related variables is connected to regional economic growth in Austria. Neither financial development (intermediation ratios) nor efficiency, concentration, bank markups and OMB presence turn out to be significant. There is weak evidence that an increased competitive behavior of banks is associated to growth as the $H$-statistic is positively significant at the $10 \%$ level. The overall bank office density again was alternatingly replaced by sectoral penetration figures in auxiliary regressions. Demographic densities of commercial and state mortgage banks are positively connected to regional income growth rates. As, however, the empirical setting does not allow the direction of causality to be pinned down effectively, it is left open whether banks from these sectors are able to support local prosperity or simply located their branches in growing regions. By all means, the result of HAKENES et al. (2009) that German savings banks can spur regional growth cannot be confirmed for Austria. 


\subsection{Some Remarks on Robustness and Model Parsimony}

The findings of this paper might suffer from being generated by using variables that are (mostly) measured contemporaneously. A possible endogeneity problem was mentioned at the outset, and some of the results suggest an interpretation using reverse causality. However, it could also be argued that adjustments in population density, economic structure and bank office density (and hence in variables based on it, such as the $\mathrm{HHI}$ and OMB activity) take too long to occur within a year. Consistent with this line of argument, HANNAN and PRAGER (2009) argue that using branching data rather than deposits in calculating the $\mathrm{HHI}$ mitigates problems related to the potential endogeneity of market structure. Other variables like income growth, Lerner indices and $\mathrm{H}$-statistics are calculated by mostly past data and thus should exhibit a large degree of predeterminedness. A robustness analysis was conducted by applying predetermined values where possible (the first lag of regional income, the intermediation ratio, and efficiency scores, as well as Lerner indices and $H$-statistics calculated from data ending in 2005) with only minimal changes in the results. Some additional exercises on using instrumental variables ${ }^{28}$ for competition measures and market structure support the suggestion that endogeneity bias does not pose a severe problem.

The extent of the covariates list is another debateable matter. Some explanatory variables are seldom significant and possibly redundant. Multicollinearity can be ruled out as a reason for statistical insignificance by an inspection of variance inflation factors. As expected, it turns out that the list of covariates can be shortened in a quite uniform fashion to end up with a parsimonious model to describe conduct and performance in local Austrian banking markets. Besides OMB activity and the economic structure dummies, also regional income and its growth rate can be removed from the list of explanatory variables with only minor losses in goodness-of-fit measures. Including population density and the intermediation ratio appears sufficient to model the demand for banking services. Even neglecting the intermediation ratio as well does not, qualitatively, affect the remaining 
results. A parsimonious model for regional bank conduct and performance might thus contain bank office and population density, as well as efficiency, concentration and competition as explanatory factors. Nevertheless, indicators of the development of the banking market and the prevalent economic structure have provided some additional interesting insights.

\section{CONCLUSIONS, IMPLICATIONS AND OUTLOOK}

Regional banking markets in Austria are studied in this paper, delineated along the borders of administrative districts. From an examination of the demographic bank penetration, it can be concluded that mainly credit cooperatives serve the poorer and less developed rural banking markets. Compared to Germany, urban districts are more strongly dominated by commercial banks, while savings banks are of less importance in general. There is a large dispersion in regional interest rate levels, which is in line with a limited mobility of capital across markets that may be associated with the spatial market segmentation pursued in large parts of the Austrian banking industry. However, there is no evidence found that the presence of banks from the respective sectors is positively related to regional development as is often claimed.

Many further detailed observations are made. For example, rural markets are characterized by high lending and low deposit rates, and are more concentrated, especially if the limited within-sector rivalry is taken into account. Differences in market concentration, however, cannot explain the regional dispersion of interest rates, bank profitability and efficiency. Branch concentration is found unrelated to competitive behavior and, quite generally, has little predictive content once other factors are applied to describe conduct and behavior in regional banking markets. Rather surprisingly, none of the analyzed dependent variables are related to the activity of out-of-market banks, as it is frequently reported by the empirical literature. It can also be observed that several of the proposed determinants do not affect price setting in regional markets in the expected manner. Local 
banking markets that are more developed exhibit a higher efficiency level, though also lower profitability. A higher bank density is connected to increased competition and lower markups, and indicates more efficient banking markets as well. As efficiency is the main determinant of bank profits and competition seems to be (mildly) indicative of stronger regional growth, economic policy should support the preservation of a fair regional bank outreach in Austria.

Spatial correlations indicate that deposit rates and bank markups are not dependent on their average values in neighboring districts, while the observed correlations in lending rates appear to be driven by a few, peculiar regions. It can therefore be concluded that administrative districts represent reasonably segregated banking markets in the case of Austria. From the customers' view, however, relevant markets may be even smaller, which would be consistent with the evidence of AMEL and BREVOORT (2005). Respective survey information is in increasing demand, especially for European countries. Research on spatial issues in banking markets would profit from an alignment of relevant and examined markets with respect to their scope. An examination of bank behavior in even more geographically restricted areas (as, for instance, in SHAFFER, 2004, and COCCORESE, 2009) may provide a useful supplement as well. By applying panel data on the geographical spread in branch networks, structural changes as well as their consequences could be portrayed on the level of regional and local banking markets.

As a connected issue, the developments in lending technologies and their public acceptance have to be tracked continuously. On the banks' side, further consolidation efforts and technological advances are desirable and comprehensible on efficiency grounds (BREVoort and Wolken, 2009; GÄRtNeR, 2009a; UdelL, 2009). Profound upheavals in regional banking markets, on the other hand, have not yet occured in Austria as well as in some countries with comparable structures. Their probability and extent depend on how large political pressures from national financial centers and supranational institutions will become. Pertaining to the strength of regional public and political interests, 
the Austrian status quo seems to be in favor of a continued predominance of local banks. Bank customers still have a strong preference for proximity and personal contact. Congruously, internet banking is generally perceived as a service enhancement, a complement to traditional distribution channels rather than a replacement (AMEL and BREVOORT, 2005; AlessandRINI et al., 2009c). The small size of banking markets, the predominance of small businesses and their ongoing dependence on bank credit are additional factors that contribute to the widespread notion of a retained importance of relationship lending in the future. KLAGGE and MARTIN (2005), for example, attribute this to the special scale and nature of small businesses' risk, while REHM (2008) concludes that the merits of the current structures in local markets may outweigh the alleged efficiency gains with increased agglomeration.

In times of financial crises, savings banks and credit cooperatives appear as strongholds of stability by maintaining the provision of credit in the economic periphery (GÄRTNER, 2009b; RAAB and WELZEL, 2011). Additionally, local banks are less prone to risk contagion as they hardly take part in globalized market segments (ALESSANDRINI et al., 2009c). It is, however, not entirely clear whether these public perceptions withstand a detailed validation of the data. Further research also in this respect could contribute to the case for regional banking markets. Quite generally, more effort is indicated with respect to the diversity of financial systems at the regional level. Local disparities in the effects of, for example, monetary and competition policies may be of interest to bank management, policy-makers, and regulators as well. Empirical evidence in this respect is especially scarce for European countries, but would be fruitful, considering the interregional variety in banking sector and industry structures.

\section{NOTES}

1. For spatial approaches to the evaluation of the European Union's cohesion policy see, for example, DALL'ERBA and Le GALLO (2008) and MOHL and HAGEN (2010). 
2. The following paragraphs focus on business finance through the banking system, but much of the argumentation applies to household financing as well. The same is true for the funding of firms through equity and venture capital markets, which is discussed by KLAGGE and MARTIN (2005) alongside their evaluation of respective policy interventions in the UK and Germany.

3. The role of soft information in the lending process is extensively discussed by Petersen and Rajan (1995), Berger and Udell (2002) and Stein (2002). For a recent study on lending to small and medium enterprises, which also lists many relevant references on the topic, see ELY and ROBINSON (2009).

4. Berger et al. (2007) and Cerqueiro, Degryse and OngenA (2009), however, cast some doubts on this proposition.

5. The portrayals of this assertion range from "wide acceptance" (FISCHER and PFEIL, 2004) to "strong evidence" (COHEN and MAZZEO, 2007).

6. MARTIN (1999) gives a description of many trends that are at work in this respect in the wake of deregulation and technological advances.

7. In the following, the focus is on evidence for small business customers. For a review of market size as perceived by households (with similar results to be deduced) see, for example, Amel, KenNiCKell and MoORE (2008) and BREVOORT and WoLKEN (2009).

8. Attempts to estimate the scope of banking markets are mainly pursued by antitrust authorities in their evaluation of potential mergers. Thereby, the extent of competition is evaluated by using bank-level data to assess, for example, cross-price elasticities. Other approaches based on price data apply time series methods (study, for example, the co-integration properties of price series) or look at the uniformity of prices within markets of a perceived scope (as, for example, HANNAN and PRAGER, 2004). 
9. According to RAJAN and ZINGALES (2003), interest group politics are an important factor in explaining differences in financial development across countries as well.

10. Banks from the following sectors are not regarded: special purpose banks (including severence funds, investment companies and real estate funds), building and loan associations, and European Member State credit institutions.

11. See, for example, FISCHER and PFEIL (2004) and SCHMIDT and TYRELL (2004) for the vast similarity of the German banking system related to these characteristics. The described ownership and network structures, as well as market segregation practices are assessed to hinder competition (EUROPEAN COMMISSION, 2007).

12. The Raiffeisen sector is the only one with a three-tier structure of primary banks, regional head institutions and one central organization.

13. Furthermore, the (regional) head institutions provide the primary banks with clearing services, product developments, marketing, research, training, and so on (see, for example, HACKETHAL, 2004, for a description of corresponding networks in German banking).

14. In general, the used data refer to 2006 and were obtained from the Austrian National Bank (Oesterreichische Nationalbank, OeNB). Financial figures for the full period (1998-2006) are applied with the dynamic calculation of competition measures $(H-$ statistics and Lerner indices).

15. An Austrian district therefore is of comparable size to an average German "Kreis," which is rated a useful market approximation by FISCHER and PFEIL (2004).

16. Branch penetration was calculated by use of the data in EUROPEAN CENTRAL BANK (2010), population figures for 2008 were taken from Eurostat.

17. Population, as the income level, is freqently used as a proxy of the demand for banking services in the empirical literature (see, for instance, COHEN and MAZZEO, 2007; RICHARDS et al., 2008; COCCORESE, 2009). 
18. In the following, the term "branch density" is used interchangeably with bank office density, although the analysis is for bank offices (headquarters and subsidiaries) throughout.

19. In Germany, savings banks exhibit the most even regional distribution according to WENGLER (2006) and BRESLER, GRÖßL and TURNER (2007).

20. Districts are defined non-neighbors (with zero entries for $w_{i j}$ ) if the Euclidean distance between their centroids exceeds a certain threshold. The cutoff distance ensures that each district has at least one neighbor, and the weights are based on actual distance. According to STAKHOVYCH and BIJMOLT (2009), however, binary weights matrices based on shared borders, on average, perform better than those based on the $n$ nearest neighbors or on distance in terms of estimation precision and a higher probability of detecting the true (spatial) model.

21. The presented correlation coefficients all are significantly different from zero. If not, this is mentioned explicitly.

22. Demographic bank office density and population density are negatively correlated (0.27). A similar result for Germany is reported by CONRAD et al. (2009).

23. The corresponding figures are very much alike those prevalent for Germany. CONRAD et al. (2009) report a demographic branch penetration for German rural areas in 2003 of 0.76 per 1000 capita (based on 102 districts). The average for the 42 Austrian districts in the Palme regions 6, 8 and 9 in 2006 is 0.78 .

24. Both the mean and the median of the $\mathrm{HHI}$ distribution for Austria are quite similar to the corresponding statistics reported for local US markets by PARK and PENNACCHI (2009), which refer to the concentration of deposits. However, the average districtlevel bank concentration based on Austrian branching data is larger than similarly obtained figures for Spanish (FERNÁNDEZ DE GUEVARA and MAUDOS, 2009), Italian (COCCORESE, 2008, 2009) and US regions (FISCHER, 2005). 
25. FISCHER (2005) reports such a pattern for the USA, where rural markets are more concentrated. By a simple inspection of an Austrian map with the districts' $\mathrm{HHI}$, the only apparent pattern to be observed is that many districts in Tyrol and Salzburg (as well as in South-West Upper Austria) tend to have a rather low bank office concentration. In these districts, however, there often are very few banks present at the municipality level, which are small and possibly serve markets that are smaller than districts. The (alpine) form of the landscape and issues of traffic and accessibility therefore also affect the possibility to draw conclusions about bank competition from the concentration level and other indicators of market structure.

26. The share of OMB branches is, at best, only weakly correlated with other covariates. Thus, its non-significance (as in other regressions described in the following) is not due to multicollinearity.

27. The efficiency level is highest for Vienna, followed by other urban (though not the suburban) and the intensive industrial regions. Intensive touristic districts exhibit the lowest efficiency scores.

28. A passable (and available) instrumental variable for competition measures is the number of distinct active banks (that operate at least one branch) in the local market. Instrument eligibility was assessed based on an F-test on excluded instruments in the first stage of Two-Stage Least Squares, and by the criterion that the instrument itself is not a significant factor in the growth regression (because there is no second suitable instrument, we cannot perform an overidentification test on instrument exogeneity). The $\mathrm{HHI}$ was tried to be instrumented as well, with the density of singlebranch banks as the most promising instrument. Applying Durbin-Wu-Hausman endogeneity tests, the null hypotheses of exogeneity is not rejected in these exercises.

\section{APPENDIX A: DATA SOURCES AND DEFINITIONS}




\section{Data Sources}

Data on the branch location for the entire population of Austrian banks in 2006 come from the Austrian National Bank (Oesterreichische Nationalbank, OeNB). Financial statements for all banks were also obtained from the OeNB. The applied figures were converted to real 2005 million euro, and a backward aggregation of data for banks merging during the sample period (1998-2006) was conducted. The full set of financial data at the bank level is, however, applied solely with the dynamic calculation of competition measures (see Appendix B). All single-bank information was aggregated to the district level (the observational unit of this study), which also applies to the indicators on which efficiency and competition measures are based.

Information on territorial classifications and the data for regional income (available for NUTS 3 regions only), population and area of land (in 2006) come from Statistics Austria. The sources of the data used to calculate national figures of demographic bank office density (per 1000 capita in 2008) for the EU 27 countries are EUROPEAN CENTRAL BANK (2010) and Eurostat (population in 2008). The classification of districts according to economic structure (described in Section 3) was extracted from PALME (1995).

\section{Variable Definitions and Dimensions}

Demographic bank office density (overall and by bank type): bank offices per 1000 capita. // Population density: capita per km2, converted to 1000 capita per km2 before used in regression analysis. // Regional income: gross regional product per capita in 2006 (in euro, converted to thousand euro before used in regressions). // Regional income growth: real growth rate of regional product per capita from 1998 to 2006 (\%). // Activity of out-ofmarket (OMB) banks: share of branches of banks with their headquarter outside the district in the total number of bank offices (\%). // Market concentration: Herfindahl-Hirschman Index $(\mathrm{HHI}$, ranging between 0 and 1$)$, the sum of the squared market shares, which are based on the number of branches in the district. // Intermediation ratio: claims against nonbanks divided by deposits from non-banks (\%). // Average ex-post interest rate on assets 
(liabilities): interest income (expenses) divided by interest-earning assets (interest-bearing liabilities). Both rates, termed lending and deposit rates in the text, are percentages. Interest-earning assets consist of interbank claims, claims against non-banks and fixedincome securities, the interest-bearing liabilities contain interbank liabilities, deposits from non-banks and secured debt issues. // Return on assets: operating profit divided by the balance sheet total (\%). // Appendix B provides details on the calculation of efficiency scores, $H$-statistics and Lerner indices.

\section{APPENDIX B: CALCULATION OF EFFICIENCY AND COMPETITION MEASURES}

\section{DEA Efficiency Scores}

Data Envelopment Analysis (DEA) is one of the frontier techniques frequently applied to examine the efficiency of so-called decision-making units (DMU). Its main advantage over other frontier methods is the possibility to conjointly consider multiple outputs. In principle, DEA is a linear programming technique to estimate the production frontier that is formed by the "best-practice" DMU. With technical efficiency considered, the individual efficiency levels from an evaluation against this benchmark are mostly expressed as the necessary proportional reduction in input utilization to reach comparable efficient DMU. The corresponding measures are called radial efficiency scores from a model with input orientation. Such indicators of relative technical inefficiency are applied in this paper, using a model with variable returns to scale (BANKER, CHARNES and COOPER, 1984). Scores are 1 for efficient districts (on the frontier), and lower for relatively inefficient ones. A value of 0.8 for a specific DMU for example, indicates that a $20 \%$ reduction of all inputs (while maintaining the output level) would be needed to reach the efficient benchmark. The selection of input and output variables is oriented on the financial intermediation approach of bank production (SEALEY and LINDLEY, 1977). The inputs considered are total funds, fixed assets and total costs. Outputs produced comprise total loans, other earning assets and non-interest income (as a proxy for off-balance sheet activities, see PASIOURAS, 2008). 
The calculated efficiency scores are corrected for an inherent bias by using the approach of SIMAR and WILSON (2007).

\section{H-Statistics}

The H-statistic, put forward by PANZAR and ROSSE (1987), represents an attept to determine the market environment that behavior is compatible with from a reduced-form revenue equation. Thereby, total revenues are modeled as a function of input prices, and the relevant measure of competition is the extent to which changes in input prices are reflected in equilibrium revenues. This approach implicitly assumes banks to be singleproduct firms, which is often rated disadvantageous (BIKKER and GROENEVELD, 2000; Gischer and Stiele, 2009). On the other hand, one needs no detailed information on output prices and output quantities (WEILL, 2004; GISCHER and STIELE, 2009). As e.g. Carbó, Humphrey, Maudos and Molyneux (2009) do, we use a translogarithmic specification in order to calculate district-level statistics from district panel data. After estimation, $H$ is obtained as the sum of the partial derivatives with respect to the input prices. The revenue function is

(3) $T R_{i t}=\lambda_{i}+\rho T R_{i, t-1}+\sum_{j=1}^{s} \alpha_{j} p_{j i t}+\sum_{j=1}^{s} \sum_{k=1}^{s} \beta_{j k} p_{j i t} p_{k i t}+\eta_{t}+\varepsilon_{i t}$

where $T R$ is total revenue, and where the prices of the $s$ input factors are denoted by $p$. All variables are in logs and time effects are considered via the year dummies. In case of perfect competition, $H$ is one, for monopoly or collusive oligopoly it is zero or negative. Monopolistic competition is indicated by values between zero and one. In this case, the $H$ statistic can be interpreted as a continuous measure of the level of competition (BIKKER and HAAF, 2002; CASU and GIRARDONE, 2006; GodDARD and WiLSON, 2009). For a more detailed description, as well as for other and special cases, see e.g. SHAFFER (2004).

The following input prices are employed: the cost of funding (the average interest rate paid on interest-bearing liabilities), the ratio of personnel expenditures to total assets, the price of fixed capital (respective value adjustments - losses and depreciation - divided by 
the value of intangible fixed assets and physical capital), and the price of equity capital (the return on equity, as in GISCHER and STIELE, 2009). Following to the recommendations of GODDARD and WILSON (2009), Equation (3) is estimated dynamically (by Difference GMM), without controlling for size or scaling the dependent variable by total assets. Additionally, no further control variables are applied. As data for the 1998-2006 period are used, the calculated measures also vary by year as the derivatives entail bank-specific input prices for each year (CARBÓ et al., 2009). The empirical part of this paper makes use of the average $H$ for each district over the sample period.

\section{Lerner Indices}

Lerner indices are calculated by, for example, ANGELINI and CETORELLI (2003) and also explained in FERnÁNDEZ de GuevarA et al. (2005) and CARBÓ VALVERDE and RodRíguez FERNÁNDEZ (2007). The empirical literature typically assumes that the total assets are a suitable measure for the flow of banking goods and services (FERNÁNDEZ DE GUEVARA, MAUdOS and PÉREZ, 2007). The price measure used to calculate the markup of price over marginal costs is therefore the average revenue per unit of assets. The marginal costs of producing one more unit of output are estimated by use of a translogarithmic cost function with one output and $s$ inputs in the form of

(4) $\quad C_{i t}=\lambda_{i}+\rho C_{i, t-1}+\sum_{j=1}^{s} \alpha_{j} p_{j i t}+\sum_{j=1}^{s} \sum_{k=1}^{s} \beta_{j k} p_{j i t} p_{k i t}+\sum_{j=1}^{s} \gamma_{j} p_{j i t} T A_{i t}+\phi_{1} T A_{i t}+\phi_{2} T A_{i t}^{2}+\eta_{t}+\varepsilon_{i t}$,

where $C$ denotes total costs and $T A$ is total assets. The input prices are defined as with estimating $H$ before. All variables, except for the time dummies, are in logarithms. Equation (4) includes the lagged value of the dependent variable as well to avoid dynamical misspecification. Marginal cost then is calculated (see, for example, ANGELINI and Cetorelli, 2003) as

(5) $M C_{i t}=\frac{C_{i t}}{T A_{i t}}\left(\sum_{j=1}^{s} \gamma_{j} p_{j i t}+\phi_{1}+2 \phi_{2} T A_{i t}\right)$,

and the Lerner index by 
(6) $L_{i t}=\frac{P_{i t}-M C_{i t}}{P_{i t}}$,

with $P$ as the price measure (total income divided by total assets). Markups range from 0 in case of perfect competition to 1 with monopolies (MAUDOS and FERNÁNDEZ DE GUEVARA, 2004).

\section{REFERENCES}

Alessandrini P., Presbitero A. F. and Zazzaro A. (2009a) Banks, Distances and Firms' Financing Constraints, Review of Finance 13, 261-307.

Alessandrini P., Presbitero A. F. and Zazzaro A. (2009b) Geographical Organization of Banking Systems and Innovation Diffusion, in AlessandRINI P., FRATIANNI M. and ZAZZARO A. (Eds) The Changing Geography of Banking and Finance, pp. 75-108. Springer, New York.

Alessandrini P., Presbitero A. F. and Zazzaro A. (2009c) Global banking and local markets: a national perspective, Cambridge Journal of Regions, Economy and Society 2, 173-192.

Alessandrini P., Presbitero A. F. and Zazzaro A. (2010) Bank size or distance: what hampers innovation adoption by SMEs?, Journal of Economic Geography 10, 845-881.

Amel D. F. and Brevoort K. P. (2005) The perceived size of small business banking markets, Journal of Competition Law and Economics 1, 771-784.

Amel D. F., Kennickell A. B. and Moore K. B. (2008) Banking Market Definition: Evidence from the Survey of Consumer Finances, Finance and Economics Discussion Series No. 2008-35, Federal Reserve Board, Washington.

Angelini P. and Cetorelli N. (2003) The Effects of Regulatory Reform on Competition in the Banking Industry, Journal of Money, Credit and Banking 35, 663-684.

ANSELIN L. (1995) Local Indicators of Spatial Association-LISA, Geographical Analysis 27, 93-115. 
Anselin L. (2009) Spatial Regression, in Fotheringham A. S. and Rogerson P. A. (Eds) The SAGE Handbook of Spatial Analysis, pp. 255-275. SAGE, Thousand Oaks.

BANkeR R. D., Charnes A. and CoOper W. W. (1984) Some models for estimating technical and scale inefficiencies in data envelopment analysis, Management Science 30, 1078-1092.

BeCK T. and Demirgüç-Kunt A. (2008) Access to Finance: An Unfinished Agenda, World Bank Economic Review 22, 383-396.

Beck T., Demirgüç-Kunt A. and Martinez Peria M. S. (2007) Reaching out: Access to and use of banking services across countries, Journal of Financial Economics 85, 234-266.

Berger A. N., Bonime S. D. and Goldberg L. G. (2004a) The Dynamics of Market Entry: The Effects of Mergers and Acquisitions on Entry in the Banking Industry, Journal of Business 77, 797-834.

Berger A. N., HASAN I. and Klapper L. F. (2004b) Further Evidence on the Link between Finance and Growth: An International Analysis of Community Banking and Economic Performance, Journal of Financial Services Research 25, 169-202.

Berger A. N., Rosen R. J. and Udell G. F. (2007) Does market size structure affect competition? The case of small business lending, Journal of Banking and Finance 31, 11-33.

Berger A. N., Saunders A., Scalise J. M. and Udell G. F. (1998) The effects of bank mergers and acquisitions on small business lending, Journal of Financial Economics 50, 187-229.

Berger A. N. and Udell G. F. (2002) Small business credit availability and relationship lending: The importance of bank organisational structure, Economic Journal 112, F32F53.

Bikker J. A. and Groeneveld J. M. (2000) Competition and Concentration in the EU Banking Industry, Kredit und Kapita/33, 62-98. 
BIKKER J. A. and HAAF K. (2002) Competition, concentration and their relationship: An empirical analysis of the banking industry, Journal of Banking and Finance 26, 21912214.

BIKKeR J. A., SpIERDIJK L. and FINNIE P. (2007) The impact of market structure, contestability and institutional environment on banking competition, Working Paper No. 156, De Nederlandsche Bank, Amsterdam.

BONACCORSI DI PATTI E. and GOBBI G. (2001) The changing structure of local credit markets: Are small businesses special?, Journal of Banking and Finance 25, 22092237.

BONAcCORSI DI PATTI E. and GoBBI G. (2007) Winners or Losers? The Effects of Banking Consolidation on Corporate Borrowers, Journal of Finance 62, 669-695.

Bresler N., GRÖßL I. and TURNER A. (2007) The Role of German Savings Banks in Preventing Financial Exclusion, in ANDERLoni L., Braga M. D. and CARLuccio E. M. (Eds) New Frontiers in Banking Services, pp. 247-269. Springer, Berlin.

Brevoort K. P. and Hannan T. H. (2006) Commercial Lending and Distance: Evidence from Community Reinvestment Act Data, Journal of Money, Credit and Banking 38, 1991-2012.

BREVoort K. P. and Wolken J. D. (2009) Does Distance Matter in Banking?, in Alessandrini P., Fratianni M. and ZazZARo A. (Eds) The Changing Geography of Banking and Finance, pp. 27-56. Springer, New York.

CAmAgni R. and CAPELlo R. (2010) Macroeconomic and territorial policies for regional competitiveness: an EU perspective, Regional Science Policy \& Practice 2, 1-20.

Carbó S., Humphrey D., Maudos J. and Molyneux P. (2009) Cross-country comparisons of competition and pricing power in European banking, Journal of International Money and Finance 28, 115-134.

Carbó-Valverde S., López del Paso R. and Rodríguez-Fernández F. (2007) Financial Innovations in Banking: Impact on Regional Growth, Regional Studies 41, 311-326. 
Carbó Valverde S. and Rodríguez Fernández F. (2007) The determinants of bank margins in European banking, Journal of Banking and Finance 31, 2043-2063.

Carbó-Valverde S., Rodríguez-Fernández F. and Udell G.F. (2009) Bank Market Power and SME Financing Constraints, Review of Finance 13, 309-340.

CASU B. and GiRARDONE C. (2006) Bank competition, concentration and efficiency in the Single European Market, Manchester School 74, 441-468.

CASU B. and MolyneuX P. (2003) A comparative study of efficiency in European banking, Applied Economics 35, 1865-1876.

Cerqueiro G., Degryse H. and Ongena S. (2009) Distance, Bank Organizational Structure, and Lending Decisions, in Alessandrini P., FratianNi M. and ZazZARo A. (Eds) The Changing Geography of Banking and Finance, pp. 57-74. Springer, New York.

Chakravarty S. P. (2006) Regional Variation in Banking Services and Social Exclusion, Regional Studies 40, 415-428.

CHICK V. and Dow S. C. (1988) A post-Keynesian perspective on the relation between banking and regional development, in ARESTIS P. (Ed) Post-Keynesian Monetary Economics: New Approaches to Financial Modelling, pp. 219-250. Edward Elgar, Aldershot.

Claessens S. and Laeven L. (2004) What Drives Bank Competition? Some International Evidence, Journal of Money, Credit and Banking 36, 563-583.

ClAEssens S. and LAEVEN L. (2005) Financial dependence, banking sector competition, and economic growth, Journal of the European Economic Association 3, 179-207.

ClinCH J. P. and O'NeILL E. (2009) Applying Spatial Economics to National Spatial Planning, Regional Studies 43, 157-178.

CocCORESE P. (2008) Bank competition and regional differences, Economics Letters 101, 13-16. 
CocCORESE P. (2009) Market power in local banking monopolies, Journal of Banking and Finance 33, 1196-1210.

Cohen A. M. and MAZZEO M. J. (2007) Market structure and competition among retail depository institutions, Review of Economics and Statistics 89, 60-74.

Collender R. N. and ShAFFeR S. (2003) Local bank office ownership, deposit control, market structure, and economic growth, Journal of Banking and Finance 27, 27-57.

Conrad A., Neuberger D. and Schneider-ReißIG M. (2009) Geographic and Demographic Bank Outreach: Evidence from Germany's Three-Pillar Banking System, Kredit und Kapita/42, 377-411.

DALL'ERBA S. and LE GALlo J. (2008) Regional convergence and the impact of European structural funds over 1989-1999: A spatial econometric analysis, Papers in Regional Science 87, 219-245.

DEEG R. and LÜTZ S. (2000) Internationalization and Financial Federalism: The United States and Germany at the Crossroads?, Comparative Political Studies 33, 374-405.

Degryse H. and OngenA S. (2005) Distance, Lending Relationships, and Competition, Journal of Finance 60, 231-266.

DEGRYSE H. and ONGENA S. (2007) The impact of competition on bank orientation, Journal of Financial Intermediation 16, 399-424.

Degryse H. and OngenA S. (2008) Competition and Regulation in the Banking Sector: A Review of the Empirical Evidence on the Sources of Bank Rents, in THAKOR A. V. and Bоот A. W. A. (Eds) Handbook of Financial Intermediation and Banking, pp. 483-554. Elsevier, Amsterdam.

Dow S. C. (1999) The Stages of Banking Development and the Spatial Evolution of Financial Systems, in MARTIN R. (Ed) Money and the Space Economy, pp. 31-48. Wiley, Chichester.

ELSAS R. (2005) Empirical determinants of relationship lending, Journal of Financial Intermediation 14, 32-57. 
ELY D. P. and RoBinson K. J. (2009) Credit Unions and Small Business Lending, Journal of Financial Services Research 35, 53-80.

EUROPEAN CENTRAL BANK (2010) Structural indicators for the EU banking sector. Frankfurt.

EUROPEAN COMMISSION (2007) Report on the retail banking sector inquiry. Brussels.

EUROPEAN COMmission (2008) Financial Services Provision and Prevention of Financial Exclusion. Brussels.

FERnÁNdez de Guevara J. and Maudos J. (2009) Regional Financial Development and Bank Competition: Effects on Firms' Growth, Regional Studies 43, 211-228.

Fernández de Guevara J., Maudos J. and Pérez F. (2005) Market Power in European Banking Sectors, Journal of Financial Services Research 27, 109-137.

Fernández de Guevara J., Maudos J. and PÉrez F. (2007) Integration and competition in the European financial markets, Journal of International Money and Finance 26, 26-45.

FISCHER K.-H. (2005) Banken und unvollkommener Wettbewerb, Deutscher UniversitätsVerlag, Wiesbaden.

FISCHER K.-H. and HEMPELL H. S. (2006) Regional Markets, Oligopoly, and Market Power in Banking. Mimeo.

FISCHER K.-H. and PfEIL C. (2004) Regulation and Competition in German Banking: An Assessment, in Krahnen J. P. and Schmidt R. H. (Eds) The German Financial System, pp. 291-349. Oxford University Press, Oxford.

FREEMAN D. G. (2007) Change-point analysis of the growth effects of state banking deregulation, Economic Inquiry 43, 601-613.

GÄRTNER S. (2009a) Balanced structural policy: German savings banks from a regional economic perspective, Perspectives 58, World Savings Banks Institute, Brussels.

GÄRTNER S. (2009b) Lehren aus der Finanzkrise: Räumliche Nähe als stabilisiernder Faktor, Forschung Aktuell 08/2009, Institut Arbeit und Technik, Gelsenkirchen. 
GischeR H. and Stiele M. (2009) Competition Tests with a Non-Structural Model: the Panzar-Rosse Method Applied to Germany's Savings Banks, German Economic Review 10, 50-70.

GODDARD J. and WILSON J. O. S. (2009) Competition in banking: A disequilibrium approach, Journal of Banking and Finance 33, 2282-2292.

Guiso L., SAPIENZA P. and ZingALES L. (2004) Does local financial development matter?, Quarterly Journal of Economics 119, 929-969.

HACKethal A. (2004) German Banks and Banking Structure, in KRAHNEN J. P. and SCHMIDT R. H. (Eds) The German Financial System, pp. 291-349. Oxford University Press, Oxford.

HAHN F. R. (2007a) Domestic mergers in the Austrian banking sector: a performance analysis, Applied Financial Economics 17, 185-196.

HAHN F. R. (2007b) Environmental determinants of banking efficiency in Austria, Empirica $34,231-245$.

HAHN F. R. (2008) Testing for profitability and contestability in banking: evidence from Austria, International Review of Applied Economics 22, 639-653.

Hakenes H., Schmidt R. H. and XIE R. (2009) Regional Banks and Economic Development: Evidence from German Savings Banks, Available at the SSRN eLibrary, URL http://ssrn.com/abstract=1343048.

Hakenes H. and Schnabel I. (2010) The Threat of Capital Drain: A Rationale for Regional Public Banks?, Journal of Institutional and Theoretical Economics 166, 662-689.

Hannan T. H. and Prager R. A. (2004) The competitive implications of multimarket bank branching, Journal of Banking and Finance 28, 1889-1914.

Hannan T. H. and PRAger R. A. (2009) The profitability of small single-market banks in an era of multi-market banking, Journal of Banking and Finance 33, 263-271. 
Hasan I., Koetter M. and Wedow M. (2009) Regional growth and finance in Europe: Is there a quality effect of bank efficiency?, Journal of Banking and Finance 33, 14461453.

HAUNER D. (2005) Explaining efficiency differences among large German and Austrian banks, Applied Economics 37, 969-980.

Heitfield E. and Prager R. A. (2004) The Geographic Scope of Retail Deposit Market, Journal of Financial Services Research 25, 37-55.

JAYARATNE J. and STRAHAN P. E. (1996) The finance-growth nexus: Evidence from bank branch deregulation, Quarterly Journal of Economics 111, 639-670.

KLAGGE B. (1995) Strukturwandel im Bankenwesen und regionalwirtschaftliche Implikationen, Erdkunde 49, 285-304.

KLAGGE B. and MARTIN R. (2005) Decentralized versus centralized financial systems: is there a case for local capital markets?, Journal of Economic Geography 5, 387-421.

LeVINE R. (2005) Finance and Growth: Theory and Evidence, in AGHION P. and DURLAUf S. N. (Eds) Handbook of Economic Growth, pp. 865-934. Elsevier, Amsterdam.

LeYSHON A. and ThRIFT N. (1995) Geographies of Financial Exclusion: Financial Abandonment in Britain and the United States, Transactions of the Institute of British Geographers 20, 312-341.

MARTIN R. (1999) The New Economic Geography of Money, in MARTIN R. (Ed) Money and the Space Economy, pp. 3-27. Wiley, Chichester.

MARTIN R. and SUNLEY P. (2011) The new economic geography and policy relevance, Journal of Economic Geography 11, 357-369.

MAUdos J. and FERNÁNDEZ DE GueVARA J. (2004) Factors explaining the interest margin in the banking sectors of the European Union, Journal of Banking and Finance 28, 22592281.

MAudos J. and FERnÁNDEZ dE GueVARA J. (2007) The cost of market power in banking: Social welfare loss vs. cost inefficiency, Journal of Banking and Finance 31, 2103-2125. 
Mercieca S., Schaeck K. and Wolfe S. (2009) Bank Market Structure, Competition, and SME Financing Relationships in European Regions, Journal of Financial Services Research 36, 137-155.

MoHL P. and HAGEN T. (2010) Do EU structural funds promote regional growth? New evidence from various panel data approaches, Regional Science and Urban Economics 40, 353-365.

NEUBERGER D. and RÄTHKE S. (2009) Microenterprises and multiple bank relationships: The case of professionals, Small Business Economics 32, 207-229.

PALME G. (1995) Divergenz regionaler Konvergenzclubs: Dynamische Wirtschaftsregionen in Österreich, WIFO Monatsberichte 68, 769-781.

PANZAR J. C. and Rosse J. N. (1987) Testing for "monopoly" equilibrium, Journal of Industrial Economics 35, 443-456.

PARK K. and PenNACCHI G. (2009) Harming Depositors and Helping Borrowers: The Disparate Impact of Bank Consolidation, Review of Financial Studies 22, 1-40.

PASIOURAS F. (2008) International evidence on the impact of regulations and supervision on banks' technical efficiency: an application of two-stage data envelopment analysis, Review of Quantitative Finance and Accounting 30, 187-223.

Petersen M. A. and Rajan R. G. (1995) The Effect of Credit Market Competition on Lending Relationships, Quarterly Journal of Economics 110, 407-443.

Petersen M. A. and Rajan R. G. (2002) Does Distance Still Matter? The Information Revolution in Small Business Lending, Journal of Finance 57, 2533-2570.

PILloff S. J. (1999) Does the Presence of Big Banks Influence Competition in Local Markets, Journal of Financial Services Research 15, 159-177.

PotTeR J. (2009) Evaluating Regional Competitiveness Policies: Insights from the New Economic Geography, Regional Studies 43, 1225-1236.

RAAB S. and Welzel P. (2011) The Economics of Regional Demarcation in Banking, Schmalenbach Business Review 63, 120-144. 
RAJAN R. G. and ZINGALES L. (2003) The great reversals: the politics of financial development in the twentieth century, Journal of Financial Economics 69, 5-50.

ReHM H. (2008) Das deutsche Bankensystem: Befund - Probleme - Perspektiven (Teil I), Kredit und Kapita/41, 135-159.

Richards T. J., ACHARYA R. N. and KAGAN A. (2008) Spatial competition and market power in banking, Journal of Economics and Business 60, 436-454.

SCHMIDT R. H. (2009) The Political Debate about Savings Banks, Schmalenbach Business Review 61, 366-392.

SChmidt R. H. and TYRELL M. (2004) What Constitutes a Financial System in General and the German Financial System in Particular?, in KRAHNEN J. P. and SCHMIDT R. H. (Eds) The German Financial System, pp. 291-349. Oxford University Press, Oxford.

SChNABEL I. and HAKENES H. (2006) Braucht Deutschland eine "starke private deutsche Bank"?, Kredit und Kapita/39, 163-181.

SCHNABEL I. and HAKENES H. (2007) Regionale Banken in einer globalisierten Welt, Kredit und Kapita/40, 351-380.

SEALEY C. W. and LINDLEY J. T. (1977) Inputs, outputs, and a theory of production and cost at depository financial institutions, Journal of Finance 32, 1251-1266.

SHAFFER S. (2004) Patterns of competition in banking, Journal of Economics and Business $56,287-313$.

SIMAR L. and WILSON P. W. (2007) Estimation and inference in two-stage, semi-parametric models of production processes, Journal of Econometrics 136, 31-64.

STAKHOVYCH S. and BiJMOLT T. H. A. (2009) Specification of spatial models: A simulation study on weights matrices, Papers in Regional Science 88, 389-408.

STEIN J. C. (2002) Information Production and Capital Allocation: Decentralized versus Hierarchical Firms, Journal of Finance 57, 1891-1921. 
UdELL G. F. (2009) Financial Innovation, Organizations, and Small Business Lending, in Alessandrini P., Fratianni M. and ZazZaro A. (Eds) The Changing Geography of Banking and Finance, pp. 15-26. Springer, New York.

USAI S. and VANNINI M. (2005) Banking structure and regional economic growth: lessons from Italy, Annals of Regional Science 39, 691-714.

VAnder Vennet R. (2002) Cost and Profit Efficiency of Financial Conglomerates and Universal Banks in Europe, Journal of Money, Credit and Banking 34, 254-282.

VAONA A. (2008) Regional evidence on financial development, finance term structure and growth, Empirical Economics 34, 185-201.

VeRDIER D. (2000) State and Finance in the OECD: Previous Trends and Current Change, Politics \& Society 28, 35-65.

VERDIER D. and BREEN R. (2001) Europeanization and Globalization: Politics Against Markets in the European Union, Comparative Political Studies 34, 227-262.

WARD M. D. and GLEDITSCH K. S. (2008) Spatial Regression Models. SAGE, Thousand Oaks.

WeILL L. (2004) On the Relationship Between Competition and Efficiency in the EU Banking Sectors, Kredit und Kapita/37, 329-352.

WENGLER O. (2006) Wechselwirkungen zwischen der finanzintermediatorischen Tätigkeit kommunaler Kreditinstitute und dem kommunalen Raum, Sonderheft 6/2006, Institut für Wirtschaftsforschung Halle, Halle.

Williams J. and Gardener E. P. M. (2003) The Efficiency of European Regional Banking, Regional Studies 37, 321-330. 
1

2

3

4

5

6

7

8

9

10

11

12

13

14

15

16

17

18

19

20

21

22

23

24

25

26

27

28

29

30

31

32

33

34

35

36

37

38

39

40

41

42

43

44

45

46

47

48

49

50

51

52

53

54

55

56

57

58

59

60

Table 1. Bank offices across sectors

\begin{tabular}{lrrrrrr}
\hline & S 1 & S 2 & S 3 & S 4 & S 5 & Total \\
\hline Single-branch banks & 21 & 3 & 149 & 16 & 1 & 190 \\
Multi-branch, single-municipality banks & 0 & 0 & 50 & 0 & 0 & 50 \\
Further single-market (within-district) banks & 1 & 23 & 277 & 13 & 0 & 314 \\
Multi-market banks (MMB) & 26 & 30 & 91 & 40 & 8 & 195 \\
\hline Number of banks (headquarters) & 48 & 56 & 567 & 69 & 9 & 749 \\
Number of branches & 864 & 1000 & 1692 & 481 & 164 & 4201 \\
Number of bank offices (total) & 912 & 1056 & 2259 & 550 & 173 & 4950 \\
Out-of-market branches (share, \%) & 63 & 50 & 15 & 49 & 73 & 39 \\
\hline Avg. \# of branches (multi-branch banks) & 32 & 19 & 4 & 9 & 21 & 8 \\
Median \# of branches (multi-branch banks) & 7 & 10 & 2 & 8 & 21 & 3 \\
\hline
\end{tabular}

Notes: This table presents figures on the sectoral distribution of headquarters, branches (subsidiaries), and total bank offices for 2006. S 1 (sector 1) stands for the joint-stock banks and wealth managers, S 2 for savings banks, sectors 3 and 4 contain the Raiffeisen and Volksbank credit cooperatives, and S 5 applies to the state mortgage banks. 
Table 2. Statistics for districts by economic structure

\begin{tabular}{lrrrrr}
\hline & $\begin{array}{r}\text { \# of } \\
\text { districts }\end{array}$ & $\begin{array}{r}\text { Population } \\
\text { density }\end{array}$ & $\begin{array}{r}\text { GRP per } \\
\text { capita }\end{array}$ & $\begin{array}{r}\text { Real GRP } \\
\text { growth }\end{array}$ & $\begin{array}{r}\text { Bank office } \\
\text { density }\end{array}$ \\
\hline Metropolitan area (0) & 1 & 4069 & 41500 & 4.93 & 0.32 \\
City districts (1) & 5 & 1624 & 36160 & 11.38 & 0.58 \\
Suburban districts (2) & 13 & 161 & 34308 & 12.48 & 0.54 \\
Medium-sized towns (3) & 11 & 552 & 27845 & 13.07 & 0.69 \\
Intensive industrial regions (4) & 17 & 79 & 29300 & 16.11 & 0.65 \\
Intensive touristic regions (5) & 10 & 41 & 29570 & 13.16 & 0.81 \\
Extensive industrial regions (6) & 17 & 79 & 22182 & 15.55 & 0.70 \\
Industrial periphery (8) & 10 & 45 & 21960 & 14.30 & 0.79 \\
Touristic periphery (9) & 15 & 61 & 18987 & 11.32 & 0.87 \\
\hline
\end{tabular}

Notes: This table presents the mean values of several variables for groups of districts, based on the classification of PALME (1995). The numeration as in HAHN (2008) is given in parentheses. The dimensions of the variables are as in Table 3. 
Table 3. Descriptive statistics

\begin{tabular}{lrrrrr}
\hline & Median & Mean & St. Dev. & Minimum & Maximum \\
\hline Demographic bank office density: & & & & & \\
All sectors & 0.68 & 0.71 & 0.19 & 0.32 & 1.41 \\
Joint-stock banks & 0.05 & 0.08 & 0.09 & 0 & 0.47 \\
Savings banks & 0.14 & 0.15 & 0.08 & 0 & 0.38 \\
Raiffeisen credit cooperatives & 0.34 & 0.37 & 0.17 & 0.04 & 0.96 \\
Volksbank credit cooperatives & 0.06 & 0.08 & 0.05 & 0 & 0.25 \\
State mortgage banks & 0.02 & 0.02 & 0.03 & 0 & 0.16 \\
\hline Share of OMB offices (\%) & 35.30 & 36.72 & 17.80 & 0 & 87.50 \\
HHI & 0.14 & 0.16 & 0.11 & 0.05 & 1.00 \\
HHI (multi-tier sectors consolidated) & 0.38 & 0.38 & 0.14 & 0.11 & 1.00 \\
Intermediation ratio (\%) & 75.23 & 84.17 & 32.51 & 30.47 & 218.19 \\
Rate on interest-earning assets (\%) & 4.19 & 4.24 & 0.36 & 3.21 & 6.09 \\
Rate on interest-bearing liabilities (\%) & 1.87 & 1.98 & 0.42 & 1.50 & 5.12 \\
ROA (\%) & 0.99 & 1.00 & 0.20 & 0.52 & 1.45 \\
Efficiency score & 0.97 & 0.97 & 0.01 & 0.93 & 0.99 \\
H-statistic & 0.49 & 0.48 & 0.10 & 0.08 & 0.66 \\
Lerner index (\%) & 20.26 & 20.03 & 2.80 & 12.13 & 26.54 \\
\hline Population density (capita per km ${ }^{2}$ ) & 76.37 & 250.73 & 546.07 & 20.54 & 4069.15 \\
Gross regional product (GRP) per capita (EUR) & 22900 & 26767 & 7155 & 15300 & 41500 \\
Real GDP growth (1998-2006, \%) & 13.51 & 13.64 & 5.05 & 2.64 & 26.87 \\
\hline Notes: This table presen
\end{tabular}

Notes: This table presents descriptive statistics at the district level (99 observations). All figures refer to 2006, apart from the growth rate of regional income, as well as the competition indicators ( $H$ and Lerner indices) which are based on calculations using panel data for the 1998-2006 period. OMB stands for outof-market banks, $\mathrm{HHI}$ is the abbreviation for the Herfindahl-Hirschman index calculated on the basis of the branching structure. All bank density variables are measured per 1000 capita. 
Table 4. Spatial autocorrelation and dependence

\begin{tabular}{llll}
\hline & & \multicolumn{2}{c}{ (Robust) $L M$ test } \\
& Moran's I & Spatial lag & Spatial error \\
\hline Lending rate & $0.26(0.00)^{* *}$ & $9.29(0.00)^{\star *}$ & $4.55(0.03)^{\star *}$ \\
Deposit rate & $-0.01(0.49)$ & $0.59(0.44)$ & $3.81(0.05)^{\star}$ \\
Return on assets & $0.09(0.08)^{*}$ & $6.19(0.01)^{\star *}$ & $0.79(0.37)$ \\
DEA efficiency score & $0.15(0.01)^{* *}$ & $0.48(0.49)$ & $0.76(0.38)$ \\
H-statistic & $0.09(0.07)^{\star}$ & $0.06(0.81)$ & $0.66(0.42)$ \\
Lerner index & $0.07(0.12)$ & $0.96(0.33)$ & $3.49(0.06)^{*}$ \\
Bank office density & $0.33(0.00)^{* *}$ & $0.27(0.60)$ & $0.91(0.34)$ \\
Income growth 1998-2006 & $0.23(0.00)^{* *}$ & $0.87(0.35)$ & $0.01(0.95)$ \\
\hline
\end{tabular}

Notes: This table presents results on global spatial correlation for several district-level variables, as well as on spatial dependence in regression models in which these measures are to be explained (the independent variables in these regressions can be inferred from Table 5). Spatial correlation is tested by Moran's I, (robust) $L M$ tests are employed for regression diagnostics. The spatial weights matrix imposed is a row-standardized, binary matrix based on shared borders. One asterisk indicates rejection of the null hypothesis of no spatial correlation/randomness at the $10 \%$ level, two of them indicate rejection at the $5 \%$ level. The corresponding $p$-values (for one-tailed tests) are given in parentheses. 
Table 5. Regression results

\begin{tabular}{|c|c|c|c|c|c|c|}
\hline Dependent variable: & LR & DR & ROA & EFF & $\mathrm{LI}$ & BOD \\
\hline Bank office density (BOD) & $\begin{array}{r}-0.277 \\
(0.18)\end{array}$ & $\begin{array}{l}0.238 \\
(0.25)\end{array}$ & $\begin{array}{r}-0.030 \\
(0.79)\end{array}$ & $\begin{array}{l}0.023^{* *} \\
(0.00)\end{array}$ & $\begin{array}{c}-4.585^{\star \star} \\
(0.00)\end{array}$ & \\
\hline Population density & $\begin{array}{r}-0.125 \\
(0.29)\end{array}$ & $\begin{array}{l}0.061 \\
(0.53)\end{array}$ & $\begin{array}{l}0.043^{* *} \\
(0.03)\end{array}$ & $\begin{array}{l}0.007^{\star *} \\
(0.01)\end{array}$ & $\begin{array}{c}-2.087^{* *} \\
(0.00)\end{array}$ & $\begin{array}{c}-0.078^{*} \\
(0.06)\end{array}$ \\
\hline Regional income per capita & $\begin{array}{r}-0.004 \\
(0.42)\end{array}$ & $\begin{array}{r}-0.002 \\
(0.77)\end{array}$ & $\begin{array}{l}0.003 \\
(0.26)\end{array}$ & $\begin{array}{r}0.0002 \\
(0.56)\end{array}$ & $\begin{array}{r}-0.021 \\
(0.64)\end{array}$ & $\begin{array}{c}-0.008^{*} \\
(0.06)\end{array}$ \\
\hline Income growth 1998-2006 & $\begin{array}{c}-0.011^{\star *} \\
(0.00)\end{array}$ & $\begin{array}{r}-0.003 \\
(0.51)\end{array}$ & $\begin{array}{r}0.0004 \\
(0.84)\end{array}$ & $\begin{array}{r}0.00005 \\
(0.87)\end{array}$ & $\begin{array}{r}-0.0001 \\
(0.99)\end{array}$ & $\begin{array}{l}0.001 \\
(0.80)\end{array}$ \\
\hline Intermediation ratio & $\begin{array}{l}0.004 \\
(0.23)\end{array}$ & $\begin{array}{l}0.008^{* *} \\
(0.01)\end{array}$ & $\begin{array}{c}-0.001^{* *} \\
(0.02)\end{array}$ & $\begin{array}{c}0.0001^{* *} \\
(0.02)\end{array}$ & $\begin{array}{r}-0.019 \\
(0.11)\end{array}$ & $\begin{array}{r}-0.0001 \\
(0.89)\end{array}$ \\
\hline DEA efficiency score (EFF) & $\begin{array}{l}1.046 \\
(0.61)\end{array}$ & $\begin{array}{l}1.747 \\
(0.40)\end{array}$ & $\begin{array}{l}3.246^{* *} \\
(0.00)\end{array}$ & & $\begin{array}{c}90.988^{* *} \\
(0.00)\end{array}$ & $\begin{array}{l}4.229^{* *} \\
(0.01)\end{array}$ \\
\hline $\mathrm{HHI}$ & $\begin{array}{r}-0.075 \\
(0.68)\end{array}$ & $\begin{array}{c}-0.279^{*} \\
(0.07)\end{array}$ & $\begin{array}{r}-0.013 \\
(0.87)\end{array}$ & $\begin{array}{l}0.019 \\
(0.16)\end{array}$ & $\begin{array}{r}-3.123 \\
(0.19)\end{array}$ & $\begin{array}{r}-0.117 \\
(0.56)\end{array}$ \\
\hline$H$-statistic & $\begin{array}{l}1.471^{* *} \\
(0.01)\end{array}$ & $\begin{array}{r}-0.110 \\
(0.77)\end{array}$ & $\begin{array}{l}0.579^{\star *} \\
(0.00)\end{array}$ & $\begin{array}{r}-0.004 \\
(0.78)\end{array}$ & & $\begin{array}{r}-0.057 \\
(0.80)\end{array}$ \\
\hline Lerner index (LI) & $\begin{array}{l}0.006 \\
(0.80)\end{array}$ & $\begin{array}{r}-0.032 \\
(0.16)\end{array}$ & $\begin{array}{l}0.044^{\star *} \\
(0.00)\end{array}$ & $\begin{array}{l}0.003^{\star *} \\
(0.00)\end{array}$ & & $\begin{array}{c}-0.023^{\star *} \\
(0.00)\end{array}$ \\
\hline OMB activity & $\begin{array}{l}0.002 \\
(0.15)\end{array}$ & $\begin{array}{r}-0.0002 \\
(0.91)\end{array}$ & $\begin{array}{r}-0.0003 \\
(0.67)\end{array}$ & $\begin{array}{r}-0.00003 \\
(0.73)\end{array}$ & $\begin{array}{l}0.002 \\
(0.89)\end{array}$ & $\begin{array}{r}-0.001 \\
(0.58)\end{array}$ \\
\hline Physical capital intensive & $\begin{array}{l}0.056 \\
(0.46)\end{array}$ & $\begin{array}{r}-0.020 \\
(0.80)\end{array}$ & $\begin{array}{l}0.056^{\star} \\
(0.05)\end{array}$ & $\begin{array}{r}-0.003 \\
(0.45)\end{array}$ & $\begin{array}{l}0.806 \\
(0.26)\end{array}$ & $\begin{array}{l}0.080 \\
(0.14)\end{array}$ \\
\hline Rural regions & $\begin{array}{l}0.014^{*} \\
(0.07)\end{array}$ & $\begin{array}{l}0.032 \\
(0.68)\end{array}$ & $\begin{array}{l}0.020 \\
(0.65)\end{array}$ & $\begin{array}{r}-0.002 \\
(0.62)\end{array}$ & $\begin{array}{l}1.386^{*} \\
(0.06)\end{array}$ & $\begin{array}{l}0.100^{*} \\
(0.08)\end{array}$ \\
\hline Estimation method & SLM & SEM & SLM & OLS & SEM & OLS \\
\hline Spatial parameter & $\begin{array}{l}0.340^{* *} \\
(0.01)\end{array}$ & $\begin{array}{l}0.407^{\star \star} \\
(0.01)\end{array}$ & $\begin{array}{l}0.237^{\star \star} \\
(0.01)\end{array}$ & - & $\begin{array}{l}0.342^{*} \\
(0.05)\end{array}$ & - \\
\hline R-squared & 0.354 & 0.537 & 0.706 & 0.373 & 0.457 & 0.337 \\
\hline
\end{tabular}

Notes: This table presents regression results for regional interest rates, bank profitability and efficiency, Lerner indices and bank office penetration. For the sample of 99 districts, the regression models are estimated by OLS or spatial methods with robust standard errors. If a spatial lag (SLM) or spatial error model (SEM) is applied, squared correlations between observed and predicted values for the dependent variable are reported as $R$-squared. The estimated spatial parameters $(\rho$ or $\lambda)$ are also reported in these cases. Lending and deposit rates are denoted by LR and DR, OMB stands for out-of-market banks. The dimensions of the variables are as in Table 3, except for regional income which is in thousand euro per capita, and population density which is measured in 1000 capita per square kilometer. The $p$-values for the $t$-test on non-significance are given in parentheses. This also is true for the spatial parameters, for which inference based on LM tests can be inferred from Table 4. One asterisk is for statistical significance at the $10 \%$ level, two of them indicate significance at the $5 \%$ level. 


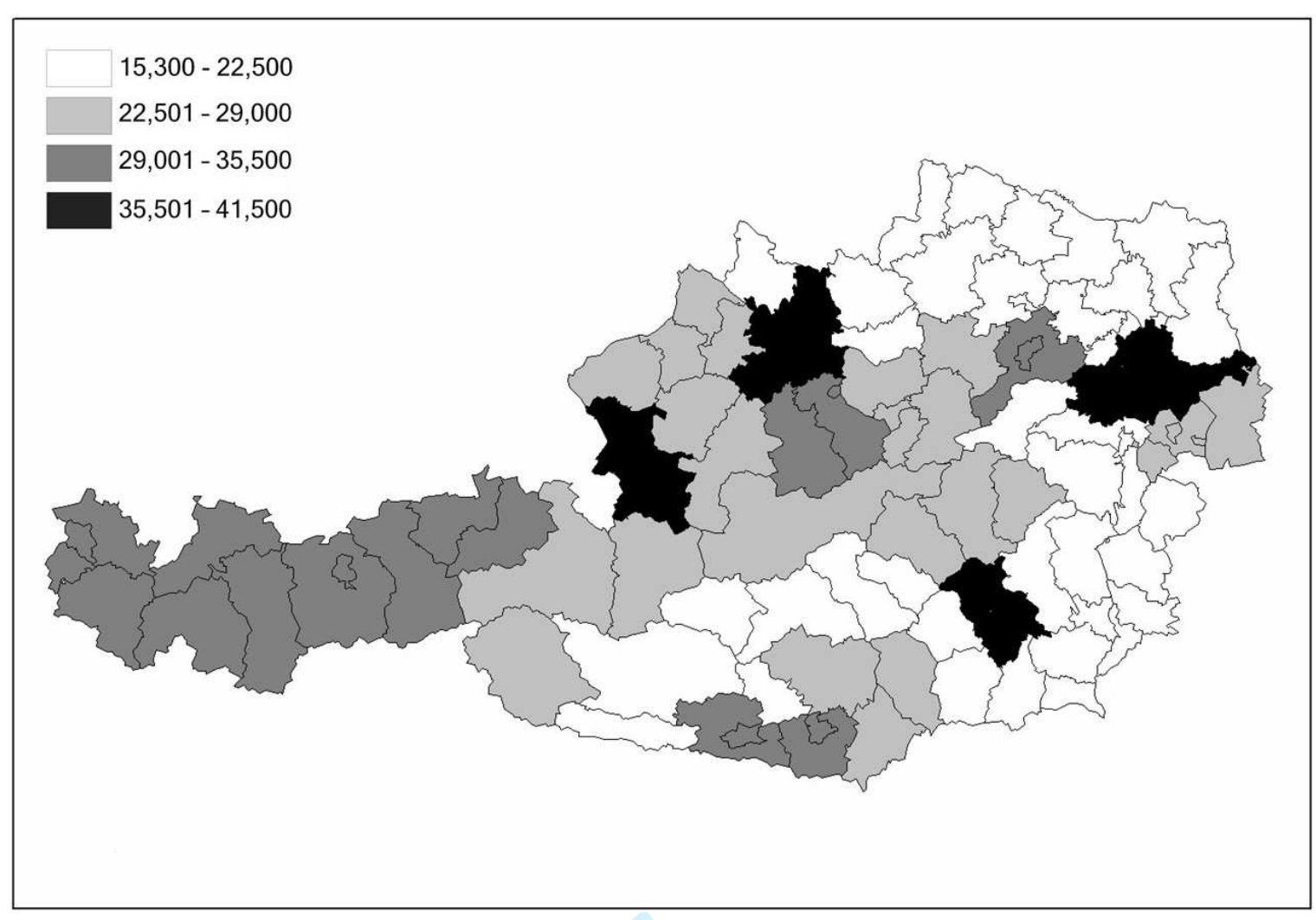

Fig. 1. Gross regional product (euro per capita, NUTS level 3, 2006) 


\section{Page 65 of 66}

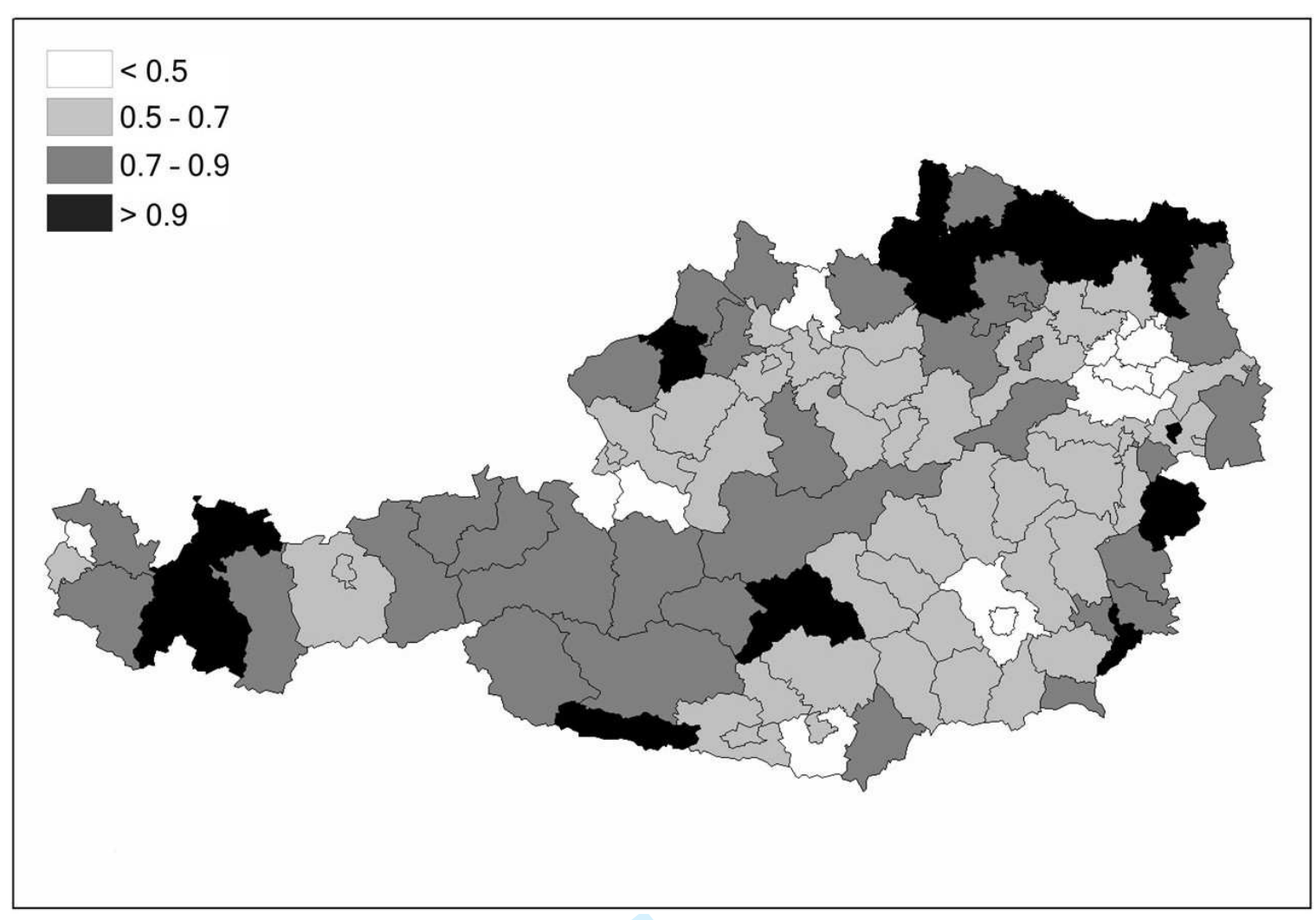

Fig. 2. Demographic bank office density

http://mc.manuscriptcentral.com/cres Email: regional.studies@fm.ru.nl 


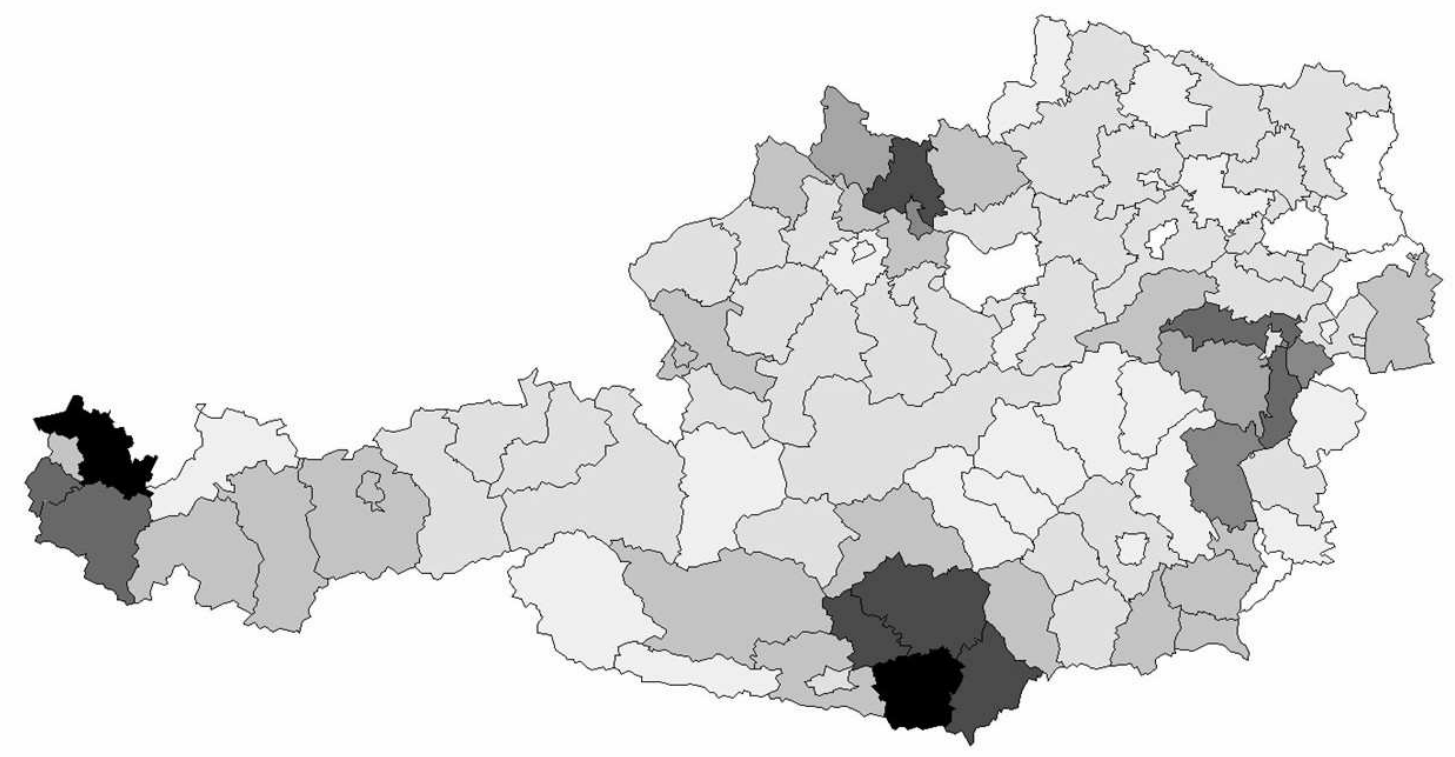

Fig. 3. Z-scores for local spatial association in the lending rate

http://mc.manuscriptcentral.com/cres Email: regional.studies@fm.ru.nl 